\title{
GSK3 $\beta$ negatively regulates TRAX, a scaffold protein implicated in mental disorders, for NHEJ-mediated DNA repair in neurons
}

\author{
Ting Chien ${ }^{1,2} \cdot$ Yu-Ting Weng ${ }^{2,4} \cdot$ Shu-Yung Chang ${ }^{2,3} \cdot$ Hsing-Lin Lai $^{2} \cdot$ Feng-Lan Chiu ${ }^{5}$ Hung-Chih Kuo ${ }^{5}$ \\ De-Maw Chuang ${ }^{6} \cdot$ Yijuang Chern ${ }^{1,2,3,4}$
}

Received: 11 May 2017 / Revised: 28 October 2017 / Accepted: 30 October 2017 / Published online: 3 January 2018

(c) The Author(s) 2017. This article is published with open access

\begin{abstract}
Translin-associated protein X (TRAX) is a scaffold protein with various functions and has been associated with mental illnesses, including schizophrenia. We have previously demonstrated that TRAX interacts with a Gs $\alpha$ protein-coupled receptor, the $\mathrm{A}_{2 \mathrm{~A}}$ adenosine receptor $\left(\mathrm{A}_{2 \mathrm{~A}} \mathrm{R}\right)$, and mediates the function of this receptor in neuritogenesis. In addition, stimulation of the $\mathrm{A}_{2 \mathrm{~A}} \mathrm{R}$ markedly ameliorates DNA damage evoked by elevated oxidative stress in neurons derived from induced pluripotent stem cells (iPSCs). Here, we report that glycogen synthase kinase 3 beta (GSK3 $\beta$ ) and disrupted-inschizophrenia 1 (DISC1) are two novel interacting proteins of TRAX. We present evidence to suggest that the stimulation of $\mathrm{A}_{2 \mathrm{~A}} \mathrm{R}$ markedly facilitated DNA repair through the TRAX/DISC1/GSK3 $\beta$ complex in a rat neuronal cell line (PC12), primary mouse neurons, and human medium spiny neurons derived from iPSCs. $\mathrm{A}_{2 \mathrm{~A}} \mathrm{R}$ stimulation led to the inhibition of GSK3 $\beta$, thus dissociating the TRAX/DISC1/GSK3 $\beta$ complex and facilitating the non-homologous end-joining pathway (NHEJ) by enhancing the activation of a DNA-dependent protein kinase via phosphorylation at $\mathrm{Thr}^{2609}$. Similarly, pharmacological inhibition of GSK3 $\beta$ by SB216763 also facilitated the TRAX-mediated repair of oxidative DNA damage. Collectively, GSK3 $\beta$ binds with TRAX and negatively affects its ability to facilitate NHEJ repair. The suppression of GSK3 $\beta$ by $A_{2 A} R$ activation or a GSK3 $\beta$ inhibitor releases TRAX for the repair of oxidative DNA damage. Our findings shed new light on the molecular mechanisms underlying diseases associated with DNA damage and provides a novel target (i.e., the TRAX/DISC1/GSK3 $\beta$ complex) for future therapeutic development for mental disorders.
\end{abstract}

\section{Introduction}

Electronic supplementary material The online version of this article (https://doi.org/10.1038/s41380-017-0007-z) contains supplementary material, which is available to authorized users.

Publisher's note: Springer Nature remains neutral with regard to jurisdictional claims in published maps and institutional affiliations.

Yijuang Chern

bmychern@ibms.sinica.edu.tw

1 Graduate Institute of Life Sciences, National Defense Medical Center, Taipei, Taiwan

2 Institute of Biomedical Sciences, Academia Sinica, Taipei, Taiwan

3 Institute of Neuroscience, National Yang-Ming University, Taipei, Taiwan

4 Program in Molecular Medicine, National Yang-Ming University and Academia Sinica, Taipei, Taiwan

5 Institute of Cellular and Organismic Biology, Academia Sinica, Taipei, Taiwan

6 Intramural Research Program, National Institute of Mental Health, National Institutes of Health, Bethesda, MD, USA
Many genes involved in DNA repair or associated with the sensitivity to DNA damage have been implicated in mental disorders (such as bipolar disorder, depression, and schizophrenia) [1-3]. Among various forms of DNA damage, DNA double-strand breaks (DSBs) are the most menacing lesions [4]. Elevated oxidative stress, which may cause oxidative DNA damage, was found in the brains of patients with bipolar disorder or schizophrenia [5, 6]. Most importantly, incomplete repair of oxidative DNA damage may aggravate the development of psychotic disorders [3, 5, 7]. DNA DSBs can be repaired via at least two principal pathways: the homologous recombination pathway and the non-homologous end-joining (NHEJ) pathway [8]. HR requires sister chromatin as the template and is error-free, while NHEJ is highly efficient but intrinsically error-prone [4]. In neurons, the NHEJ pathway is initiated by a DNAdependent protein kinase (DNA-PK) that consists of a catalytic subunit (DNA-PKcs) and a Ku protein subunit [9]. In 
response to DNA DSBs, DNA-PKcs is autophosphorylated at T2609, a step required for the recruitment of DNA repair proteins into the breakage site and the initiation of DNA repair [8].

Translin-associated protein $\mathrm{X}$ (TRAX) was initially recognized as an interacting protein of Translin, a DNA/ RNA-binding protein that controls mRNA transport, translation, DNA recombination, and RNAi production [10-13]. The exact function of TRAX remains elusive and is of great interest because the human TRAX gene is clustered with the Disrupted-in-Schizophrenia 1 (DISC1) gene at 1q42 and has been implicated in schizophrenia, autism, depression, and bipolar disorder [14-17]. The DISC1 gene is a well-recognized candidate gene for schizophrenia [18] and has been shown to inhibit glycogen synthase kinase-3 (GSK3 $\beta$ ) through a direct physical interaction [19, 20]. The functional interaction between TRAX and DISC1 has also been implicated in the control of the volume of several brain regions during neurodevelopment [21].

Accumulated evidence suggests that TRAX regulates multiple functions by interacting with various interaction partners. In response to stresses (e.g., $\gamma$-irradiation) that cause DSBs, TRAX interacts with an activator of DNA-PK (i.e., C1D), suggesting that TRAX may facilitate DNA repair [22]. We previously demonstrated that, in TRAX-null mouse embryo fibroblasts, the lack of TRAX causes reduced phosphorylation of ATM and H2AX, and subsequently impairs DNA repair in response to stresses. By interacting with ATM and stabilizing the MRN complex at DSBs, TRAX plays an important role in the ATM/H2AXmediated DNA repair machinery [23]. In addition to Translin and C1D and ATM, TRAX has several other interacting proteins, including the $\mathrm{A}_{2 \mathrm{~A}}$ adenosine receptor $\left(\mathrm{A}_{2 \mathrm{~A}} \mathrm{R}\right)[24,25]$. Adenosine is a modulator that is important for controlling the homeostatic bioenergetic network that is composed of receptor-mediated signaling pathways, cellular bioenergetics, and epigenetics [26]. Because adenosine has been functionally associated with dopamine and glutamate, the major neurotransmitter systems involved in schizophrenia pathophysiology, the modulation of the adenosinergic system might, therefore, be an important therapeutic approach for both the genesis and treatment of schizophrenia [26, 27]. In line with this hypothesis, adenosine augmentation is believed to be beneficial for schizophrenia [28, 29]. There are four types of adenosine receptors $\left(A_{1}\right.$, $\mathrm{A}_{2 \mathrm{~A}}, \mathrm{~A}_{2 \mathrm{~B}}$ and $\mathrm{A}_{3}$ ). The $\mathrm{A}_{2 \mathrm{~A}} \mathrm{R}$ is a G-protein-coupled receptor and is located in many brain areas, with the highest level of expression in the striatum [30]. Stimulation of the $\mathrm{A}_{2 \mathrm{~A}} \mathrm{R}$ activates cAMP/PKA signaling and evokes a TRAXdependent pathway required for neuronal differentiation $[24,25]$. Interestingly, the $\mathrm{A}_{2 \mathrm{~A}} \mathrm{R}$ level is differentially altered in different brain regions of patients with schizophrenia [31, 32], suggesting that the function of the $\mathrm{A}_{2 \mathrm{~A}} \mathrm{R}$ might be critical for the development of schizophrenia. In addition, the activation of the $\mathrm{A}_{2 \mathrm{~A}} \mathrm{R}$ reduces oxidative stress, which is believed to contribute to the pathogenesis of schizophrenia [5], in a rat neuron-like cell line [33] and in human medium spiny neurons (MSNs) derived from induced pluripotent stem cells (iPSCs) [34].

In the present study, we investigated the molecular mechanism underlying the TRAX-dependent protection of rodent neurons and human MSN-like neurons from oxidative stress-evoked DNA damage. Our findings showed that TRAX forms a complex with DISC1 and GSK3 $\beta$ at resting conditions. GSK $3 \beta$ is a serine/threonine kinase that controls multiple functions via phosphorylation-mediated signal cascades. The inhibition of GSK3 $\beta$ by $\mathrm{A}_{2 \mathrm{~A}} \mathrm{R}$ activation or a GSK3 $\beta$ inhibitor (SB216763) released TRAX from the complex to mediate the DNA-PK-dependent NHEJ repair. The results of the present study shed new light on the mechanistic role of DISC1/GSK3 $\beta$ in regulating DNA damage caused by elevated oxidative stress in neurons. Drugs that target the TRAX/DISC1/GSK3 $\beta$ complex provide novel possibilities for the development of therapeutic treatments for mental disorders (such as schizophrenia and bipolar disorder).

\section{Materials and methods}

\section{Cell cultures and transfection}

PC12 cells were obtained from the American Type Culture Collection (Manassas, VA, USA) and cultured in Dulbecco's modified Eagle's medium (DMEM; Invitrogen, Carlsbad, CA, USA) supplemented with 5\% heat-inactivated fetal bovine serum (FBS) and 10\% heat-inactivated horse serum [34]. Cells were incubated in a humidified incubator at $37^{\circ} \mathrm{C}$ with $10 \% \mathrm{CO}_{2}$. The permanent PC12-shTRAX cell line was established via the transfection of $\mathrm{PC} 12$ cells with the linearized pSuper-shTRAX-F vector, as previously described [24], which contains a small hairpin RNA (5'GCTGTACACCTTGAAACAG-3') for the knockdown of TRAX in PC12 cells and a neomycin resistance gene as a selective marker. The colonies were selected by G418 (500 $\mu \mathrm{g} / \mathrm{ml}$; Biochrom, Holliston, MA, USA) for 2 weeks. Down-regulation of TRAX was confirmed by Western blotting to assess the amount of TRAX in PC12-shTRAX cells. PC12-shTRAX cells were cultured in DMEM supplemented with 5\% heat-inactivated FBS, 10\% heatinactivated $\mathrm{HS}$ and G418 $(250 \mu \mathrm{g} / \mathrm{ml})$. Cells were incubated in a humidified $37^{\circ} \mathrm{C}$ incubator with $10 \% \mathrm{CO}_{2}$.

Primary hippocampal neurons were prepared as described previously [35]. Cells were maintained under $5 \% \mathrm{CO}_{2}$ for 14 days and subjected to the indicated treatments. 
Human iPSCs were derived from normal subjects and differentiated into MSN-like neurons as described previously [34].

\section{Lentivirus preparation and infection}

Lentiviruses were prepared using standard procedures by the National RNAi Core Facility (NRC), Academia Sinica. PC12 cells were infected with lentiviruses at the multiplicity of infection (MOI) of 50 in the presence of polybrene $(8 \mu \mathrm{g} /$ $\mathrm{ml}$ ) (Sigma-Aldrich) for 3 days and subjected to the subsequent treatments.

iPSC-derived neurons were infected with lentiviruses as previously described [34]. Briefly, neurons were infected with the desired lentiviruses at the MOI of 10 for 3 days and subjected to the indicated treatment(s).

\section{Constructs and site-directed point mutation}

The pcDNA3.1-rTRAX-V5, pcDNA3.1- $\Delta$ NLS-rTRAX-V5 and pSuper-shTRAX-F constructs were developed as previously described [24]. The DNA fragments of rat GSK3 $\beta$ and human GSK3 $\beta$ were amplified from cDNA of PC12 cells and HEK293T cells, respectively, and cloned into pcDNA3.1-Myc (Invitrogen) using polymerase chain reaction (PCR) and the primers described in Table S1. The DNA fragment of rat DISC1 was amplified from the cDNA of PC12 cells by PCR and cloned into pCMV-Tag2B (Stratagene, La Jolla, CA, USA) using the primers listed in Table S1.

The point mutation of GSK3 $\beta$-S9A was created by a method described earlier [36] using standard protocols and site-specific primers (5'-GACCGAGAACCACCG- CCTTTG CGGAGAGC-3' and 5'- GCTCTCCGCAAAGGCGGTGG TTCTCGGTC-3'). pLKO1-h-shTRAX and pLKO1-r-shC1D were purchased from the NRC, Academia Sinica (Taipei, Taiwan).

\section{Sodium dodecyl sulfate polyacrylamide gel electrophoresis (SDS-PAGE) and Western blot analysis}

SDS-PAGE and Western blot analysis were performed as described previously [24]. Briefly, cell lysates were prepared by vibrating cells in a RIPA buffer $(150 \mathrm{mM}$ Sodium Chloride, Triton-X 100, $0.5 \%$ sodium deoxycholate, $0.1 \%$ SDS, $50 \mathrm{mM}$ Tris-Cl; $\mathrm{pH} 8.0$ ). The protein concentration was determined with the Bio-Rad Protein Assay (Bio-Rad, Hercules, CA, USA). The immunoreactive bands were visualized via a light emitting non-radioactive method (ECL; Millipore). The sources of the antibodies used in western blot analyses are listed below: anti- $\gamma \mathrm{H} 2 \mathrm{AX}$ (Millipore; 05-636), anti- $\alpha$-tubulin (Genetex, Irvine, CA, USA;
GTX76511), anti-TRAX [25], anti- $\beta$-actin (Genetex; GTX11003), anti-DNA-PK ${ }_{\mathrm{CS}}$ Thr2609 (Abnova, Cambridge, United Kingdom; PAB10324), anti-DNA-PK $\mathrm{CS}_{\mathrm{C}}$ (Abcam, Cambridge, United Kingdom; ab1832), antiGSK3 $\beta$ Ser9 (Cell Signaling, Danvers, MA, USA; 9336), anti-GSK3 $\beta$ (Genetex; GTX83315), anti- $\beta$-catenin (Genetex; GTX61089), anti-DISC1 (Thermo; 710203), anti- $\mathrm{A}_{2 \mathrm{~A}} \mathrm{R}$ (Santa cruz, Dallas, Texas, USA; SC-32261), and antiPARP (Genetex; GTX112864).

\section{Immunofluorescence staining and quantitation}

Immunofluorescence staining was performed as described previously [37]. The images were examined with a laserscanning confocal microscope (LSM 700, Carl Zeiss; Oberkochen, Germany). Quantitative analysis was performed by determining the immunofluorescence intensity of the target protein(s) using ImageJ [38] and normalized with the cell number on each slide. At least 100 cells were scored in each condition. The sources of the antibodies used in immunofluorescence staining are listed below: anti- $\gamma \mathrm{H} 2 \mathrm{AX}$ (Millipore; 05-636), anti-TUJ1 (Biolegend; MRB435P), and anti-TRAX [25].

\section{Immunoprecipitation}

Cell lysates were prepared by vibrating cells in a nondenaturing lysis buffer (137 mM NaCl, $1 \%$ NP-40, $20 \mathrm{mM}$ Tris-Cl pH 8.0, 2 mM EDTA) for $1 \mathrm{~h}$ at $4{ }^{\circ} \mathrm{C}$. The Protein A or G Dynabeads ${ }^{\circledR}$ (Novex $^{\mathrm{TM}}$, Thermo Fisher Scientific, Waltham, MA, USA) were incubated with a proper primary antibody $(2 \mu \mathrm{g} / \mathrm{per}$ sample $)$ at RT for $10 \mathrm{~min}$. The cell lysates $(1-3 \mathrm{mg})$ were added to the Dynabead-antibody (Ab) complex at RT and gentlely rotated for $1 \mathrm{~h}$. Immunoprecipitates were collected by placing the tube containing the reaction mixture onto a Magnetic Separation Rack for 1 min to collect the Dynabead-Ab complexes, which was subsequently washed with a washing buffer $(0.02 \%$ Tween20 in PBS) three times. The immunoprecipitated proteins were released from the immunocomplexes by adding $30 \mu \mathrm{l}$ of the SDS-PAGE reducing sample buffer $(50 \mathrm{mM}$ Tris$\mathrm{HCl}$ (pH 6.8), $10 \%$ glycerol, $2 \%$ SDS, $0.1 \%$ bromophenol blue, and $1 \% \quad \beta$-mercaptoethanol) to the collected Dynabead-Ab complexes and boiled at $95^{\circ} \mathrm{C}$ for $10 \mathrm{~min}$.

\section{Neutral comet assay}

The Neutral Comet assay was performed as described previously [39]. Briefly, DNA damage (DNA breaks) was evaluated with a comet assay kit (TREVIGEN, Gaithersburg, MD, USA) following the manufacturer's protocol. Cells at a density of $1 \times 10^{5} / \mathrm{ml}$ were combined with molten LMAgarose (at $\left.37^{\circ} \mathrm{C}\right)$ at a ratio of $1: 10(\mathrm{v} / \mathrm{v})$, pipetted onto 
a CometSlide, lysed for $1 \mathrm{~h}$, and subjected to electrophoresis. At least 100 cells were scored in each sample and were analyzed with the comet 5.0 image system (Kinetic Imagine, Liverpool, UK).

\section{Annexin V apoptosis detection assay}

The Annexin V apoptosis detection assay was performed as described previously [40]. Briefly, cells were resuspended in a binding buffer $\left(140 \mathrm{mM} \mathrm{NaCl}, 2.5 \mathrm{mM} \mathrm{CaCl}_{2}, 10 \mathrm{mM}\right.$ HEPES, pH 7.4) at a density of $10^{6} / \mathrm{ml}$. The cell suspension $(100 \mu \mathrm{l})$ was incubated with Annexin V-FITC $(10 \mu \mathrm{l})$ and propidium iodide $(20 \mu \mathrm{g} / \mathrm{ml}, 5 \mu \mathrm{l})$ (Enzo, Farmingdale, NY, USA) for $10 \mathrm{~min}$ and analyzed via flow cytometry (LSR 11, Biosciences, San Jose, CA, USA).

\section{Proximity ligation assay (PLA)}

The PLA analysis was performed as described previously [41]. Cells were fixed with $4 \%$ paraformaldehyde for 20 min and then treated with $0.05 \%$ NP-40 in PBS for 20 min. PLA was carried out following the manufacturer's protocol. The mages were examined with a laser-scanning confocal microscope (LSM700-meta). Quantitative analysis was performed by measuring the number of PLA signals, which were normalized to the cell number. At least 100 cells were evaluated for each condition. The sources of the antibodies used in PLA are listed below: anti-TRAX [25], anti-DISC1 (Thermo; 710203), and antiGSK3 $\beta$ (Genetex; GTX83315).

\section{NHEJ assay, DNA extraction and quantitative PCR (qPCR)}

The NHEJ assay was performed as described previously with slight modifications [42]. To generate DSBs, pEGFPC3 was cleaved by NheI at a site between the promoter and the GFP reporter gene. The linearized DNA was resolved and isolated from electrophoresis gels with a Gel Extraction kit (Geneaid, New Taipei City, Taiwan) and transfected into cells with Lipofectamine 2000 as described above. Cells were co-transfected with the linearized pEGFP-C3 and a control circular DNA (pDsRed-monomer-C1) that assessed transfection efficiency at a ratio of 9:1 (w/w). 2 days posttransfection, transfected plasmids inside the cells were purified with the UltraClean ${ }^{\mathrm{TM}}$ Tissue \& Cells DNA Isolation Kit (MO BIO, Carlsbad, CA, USA), and subjected to qPCR via an ABI PRISM 7700 Sequence Detection System (Life Technologies, Carlsbad, CA, USA), the SYBR Green PCR Master Mix (Life Technologies), and the primers (pEGFP-C3-NHEJ-F and pEGFP-C3-NHEJ-R for the linearized pEGFP-C3; pDsRed-C1-F and pDsRed-C1-R for pDsRed-monomer-C1) listed in Table S1. The amount of
DNA amplified using pEGFP-C3-NHEJ-F and pEGFP-C3NHEJ-R reflected the amount of repaired DNA, and the values were normalized to those obtained from the amplification of pDsRed-C1-F and pDsRed-C1-R to control for transfection efficiency.

\section{Statistical analysis}

All experiments were reliably and independently conducted at least three times. The data are shown as the mean \pm SEM. Our data meet the assumption of normal distribution. No data was excluded. Imaging quantitation was performed blinded. SigmaPlot (Version 10; Systat Software Inc.; San Jose, CA, USA) was used for data analysis. Statistical significance was determined by one or two-way analysis of variance, or Student's $t$ test as indicated. $P$ values $<0.05$ are considered statistically significant.

\section{Results}

\section{TRAX mediates the protective effect of the $A_{2 A} R$ on DNA damage in rodent and human neurons}

We previously demonstrated that the stimulation of the $\mathrm{A}_{2 \mathrm{~A}} \mathrm{R}$ rescues oxidative stress-induced DNA damage and apoptosis in human iPSC-derived MSNs via a cAMP/PKAdependent pathway [34]. Because TRAX is an $A_{2 A} R$ interacting protein [25] and plays a central role in the ATMmediated DNA repair [23], TRAX might contribute to the $\mathrm{A}_{2 \mathrm{~A}} \mathrm{R}$-induced repair of DNA damage evoked by elevated oxidative stress. We first assessed whether the activation of the $\mathrm{A}_{2 \mathrm{~A}} \mathrm{R}$ also rescued oxidative DNA damage in rodent neurons as in human neurons. PC12 cells were treated with $\mathrm{H}_{2} \mathrm{O}_{2}(100 \mu \mathrm{M})$ for $4 \mathrm{~h}$ to induce oxidative DNA damage. As shown in Fig. 1a, treatment with $\mathrm{H}_{2} \mathrm{O}_{2}$ evoked significant DNA DSBs as detected with the neutral comet assay. Pretreatment with an $\mathrm{A}_{2 \mathrm{~A}} \mathrm{R}$-specific agonist, CGS21680 (CGS) [24] effectively reduced the DNA DSBs (Fig. 1a). We next evaluated DNA damage in PC12 cells by $\mathrm{H}_{2} \mathrm{O}_{2}(100 \mu \mathrm{M})$ from 1 to $4 \mathrm{~h}$ by measuring the level of a DNA DSBs marker $(\gamma \mathrm{H} 2 \mathrm{AX})$ [43] via Western blot analysis. Pretreatment of PC12 cells with CGS consistently reduced the amount of $\gamma \mathrm{H} 2 \mathrm{AX}$ up to $4 \mathrm{~h}$ (Fig. 1b). Similarly, exposure to $\mathrm{H}_{2} \mathrm{O}_{2}$ increased the number of $\gamma \mathrm{H} 2 \mathrm{AX}$ foci and the level of $\gamma \mathrm{H} 2 \mathrm{AX}$, which can be ameliorated by pretreatment with CGS in mouse hippocampal neurons (Fig. 1c). Such oxidative stress-induced DNA damage, if unrepaired, would lead to apoptosis, as determined by the level of Annexin V (Fig. 1d). Pretreatment with CGS reduced not only the amount of $\gamma \mathrm{H} 2 \mathrm{AX}$ but also the level of Annexin $\mathrm{V}$, evoked by $\mathrm{H}_{2} \mathrm{O}_{2}$ (Fig. 1d). Since an $\mathrm{A}_{2 \mathrm{~A}} \mathrm{R}$ selective inhibitor (SCH58261, SCH) effectively eliminated 
A

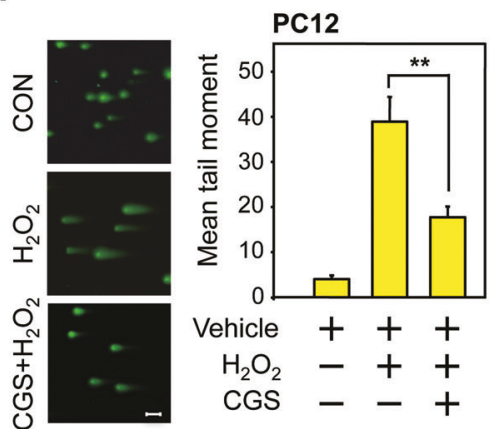

B

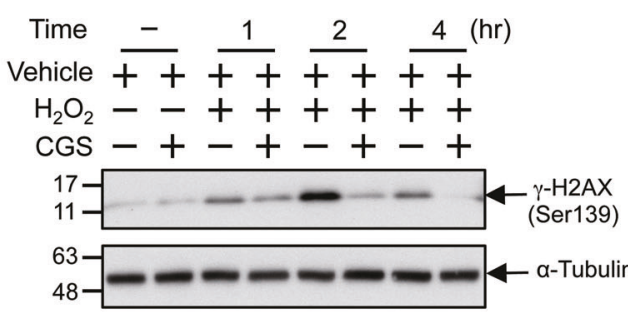

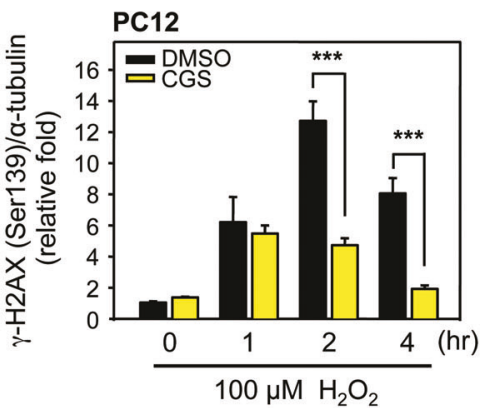

D

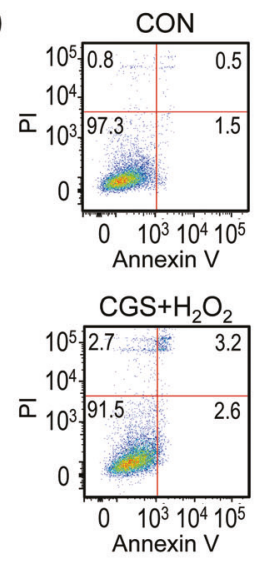

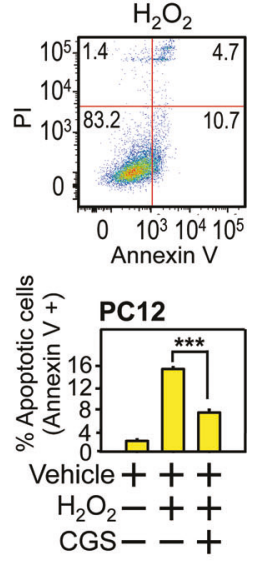

Hippocampal neurons

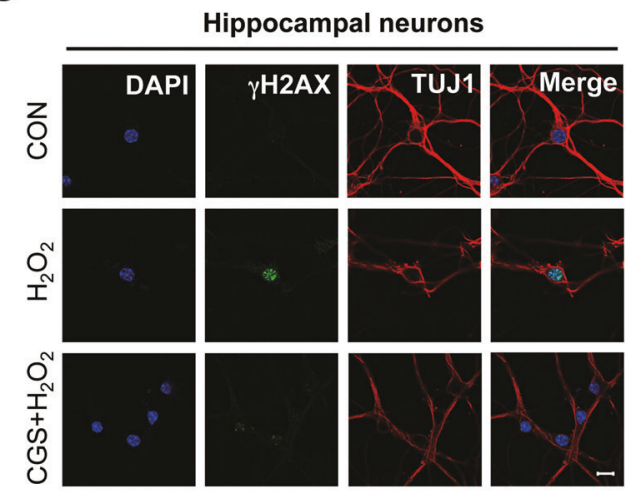

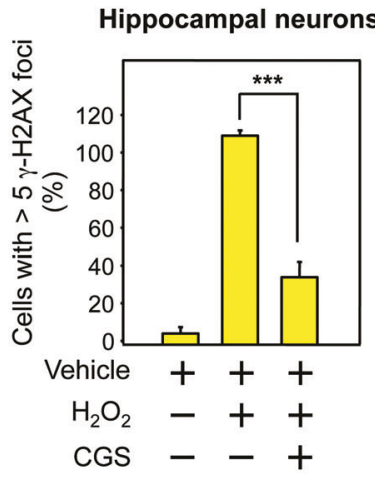

F

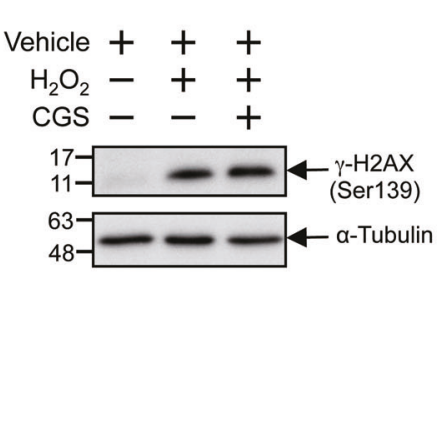

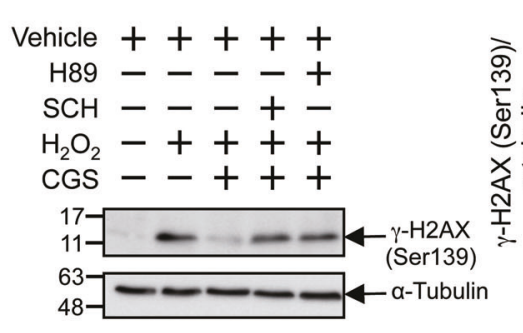

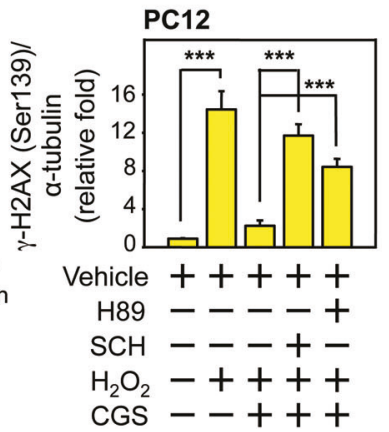

E

Fig. 1 Activation of the $\mathrm{A}_{2 \mathrm{~A}} \mathrm{R}$ ameliorates oxidative stress-induced DNA damage and toxicity. a PC12 cells were treated with an agonist of the $A_{2 \mathrm{~A}} \mathrm{R}$ (CGS21680, CGS; $10 \mu \mathrm{M}$ ) or vehicle for $1 \mathrm{~h}$ to activate the $\mathrm{A}_{2 \mathrm{~A}} \mathrm{R}$, followed by the addition of $\mathrm{H}_{2} \mathrm{O}_{2}(100 \mu \mathrm{M})$ for $4 \mathrm{~h}$. The extent of DNA damage was analyzed via the neutral comet assay. The mean tail moment was quantified by using COMETscore. v1.5 software. Scale bar, $50 \mu \mathrm{m}$. b PC12 cells were pretreated with CGS $(10 \mu \mathrm{M})$ or vehicle for $1 \mathrm{~h}$ and then treated with $\mathrm{H}_{2} \mathrm{O}_{2}(100 \mu \mathrm{M})$ for the indicated time. Cells were lysed and subjected to SDS-PAGE and Western blot analysis using the anti- $\gamma \mathrm{H} 2 \mathrm{AX}$ and anti- $\alpha$-Tubulin antibodies as indicated. The amount of target protein was quantified and normalized to that of $\alpha$-Tubulin, the loading control. These experiments were repeated three times. c Primary hippocampal neurons (DIV14) harvested from wild-type B6/C57 mice were treated with CGS $(10 \mu \mathrm{M})$ or vehicle for $1 \mathrm{~h}$ and then treated with $\mathrm{H}_{2} \mathrm{O}_{2}(100$ $\mu \mathrm{M})$ for $2 \mathrm{~h}$. DNA damage was assessed by determining the number of DNA foci per cell by immunofluorescence staining using the anti$\gamma \mathrm{H} 2 \mathrm{AX}$ antibody (green) in neurons identified by a neuronal marker (TUJ1, red). The percentage of cells with $>5 \gamma \mathrm{H} 2 \mathrm{AX}$ foci per cell in at least 100 cells were determined in each condition. Scale bar, 10 $\mu \mathrm{m}$. d PC12 cells were treated with CGS $(10 \mu \mathrm{M})$ or vehicle for $1 \mathrm{~h}$, followed by treatment with $\mathrm{H}_{2} \mathrm{O}_{2}(100 \mu \mathrm{M})$ for $4 \mathrm{~h}$. The survival of these treated cells was measured using the Annexin $\mathrm{V}$ apoptosis detection assay kit. Cells were co-stained with Annexin V-FITC and propidium iodide (PI) for 10 min followed by flow cytometric analysis. These experiments were repeated three times. e, f PC12 cells were treated with an inhibitor of protein kinase $\mathrm{A}(\mathrm{H} 89 ; 10 \mu \mathrm{M})$, an $\mathrm{A}_{2 \mathrm{~A}} \mathrm{R}$-selective inhibitor (SCH58261, SCH; $1 \mu \mathrm{M}$ ) or vehicle for 30 min and then treated with CGS $(10 \mu \mathrm{M})$ or vehicle for $1 \mathrm{~h}$ to activate the $\mathrm{A}_{2 \mathrm{~A}} \mathrm{R}$, followed by the addition of $\mathrm{H}_{2} \mathrm{O}_{2}(100 \mu \mathrm{M})$ for $4 \mathrm{~h}(\mathbf{e})$. A123, a cAMP-dependent protein kinase (PKA)-deficient PC12 cell line, was treated with CGS $(10 \mu \mathrm{M})$ or vehicle for $1 \mathrm{~h}$ to activate the $\mathrm{A}_{2 \mathrm{~A}} \mathrm{R}$, followed by treatment with $\mathrm{H}_{2} \mathrm{O}_{2}(100 \mu \mathrm{M})$ for $4 \mathrm{~h}(\mathbf{f})$. Cells were lysed and subjected to SDS-PAGE, followed by Western blot analysis using the anti- $\gamma \mathrm{H} 2 \mathrm{AX}$ and anti- $\alpha$-Tubulin antibodies as indicated. The amount of target protein was quantified and normalized to that of $\alpha$-Tubulin, the loading control. These experiments were repeated three times. Data are presented as the mean \pm SEM from at least three independent experiments. $* * P<0.01$, $* * * P<0.001$ compared to control 
A
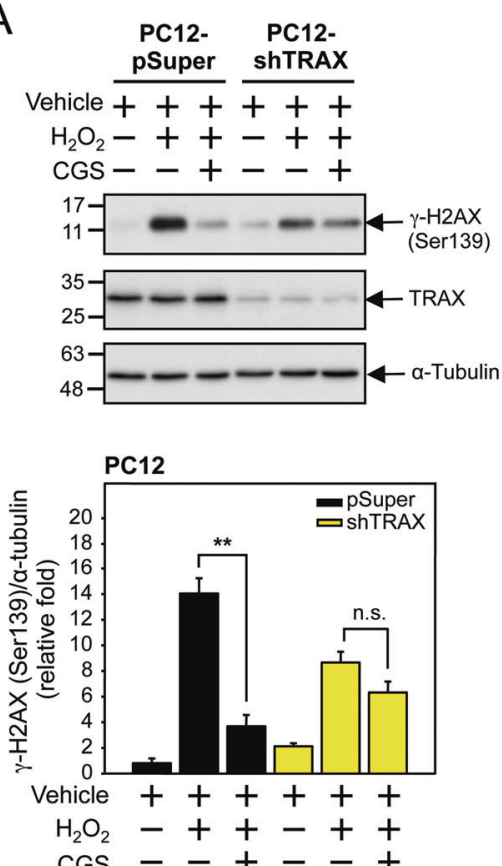

D
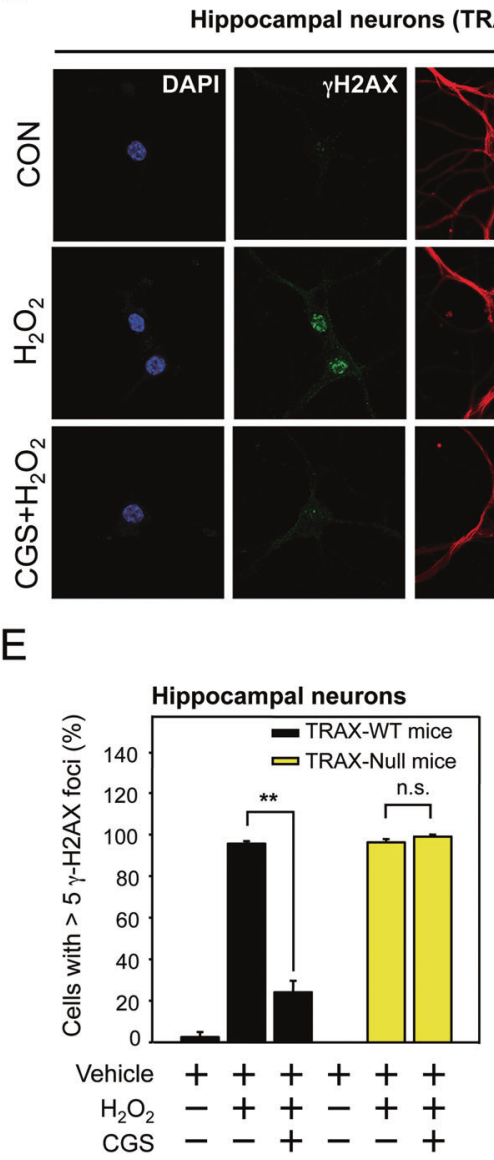

D
E
B

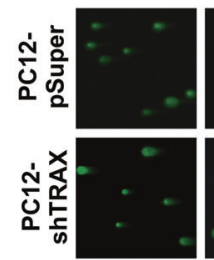

Vehicle +

$\mathrm{H}_{2} \mathrm{O}_{2}-$

CGS -

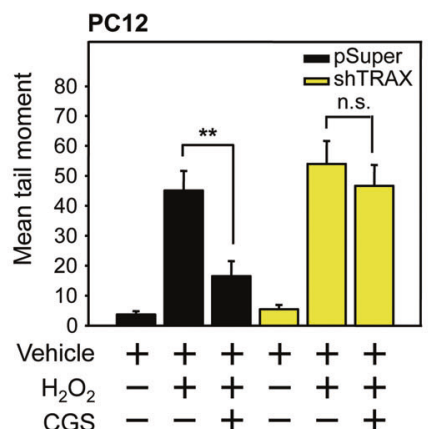

C

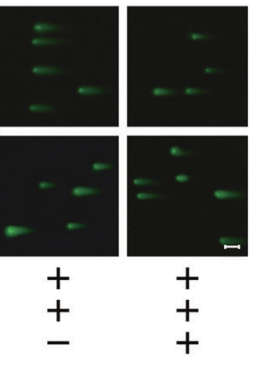

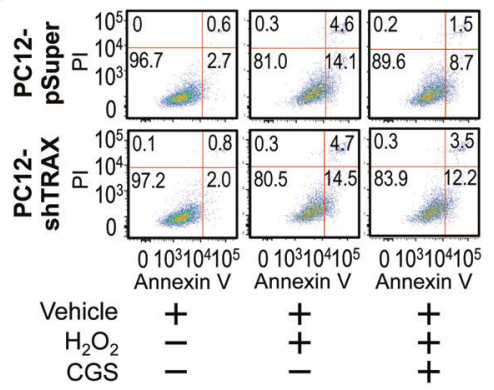

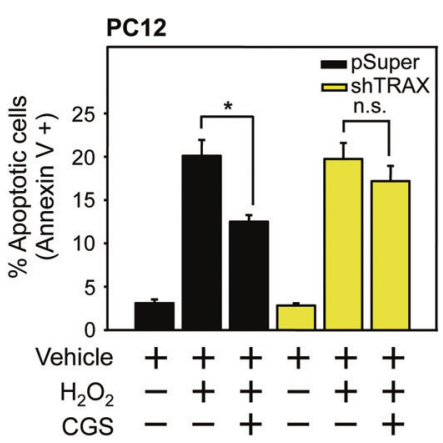

C

$-+--+$
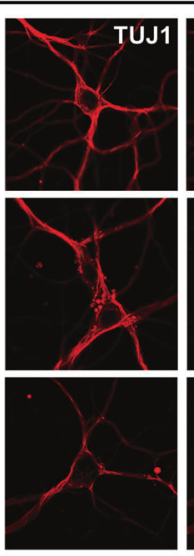

F

Hippocampal neurons (TRAX-Null mice)
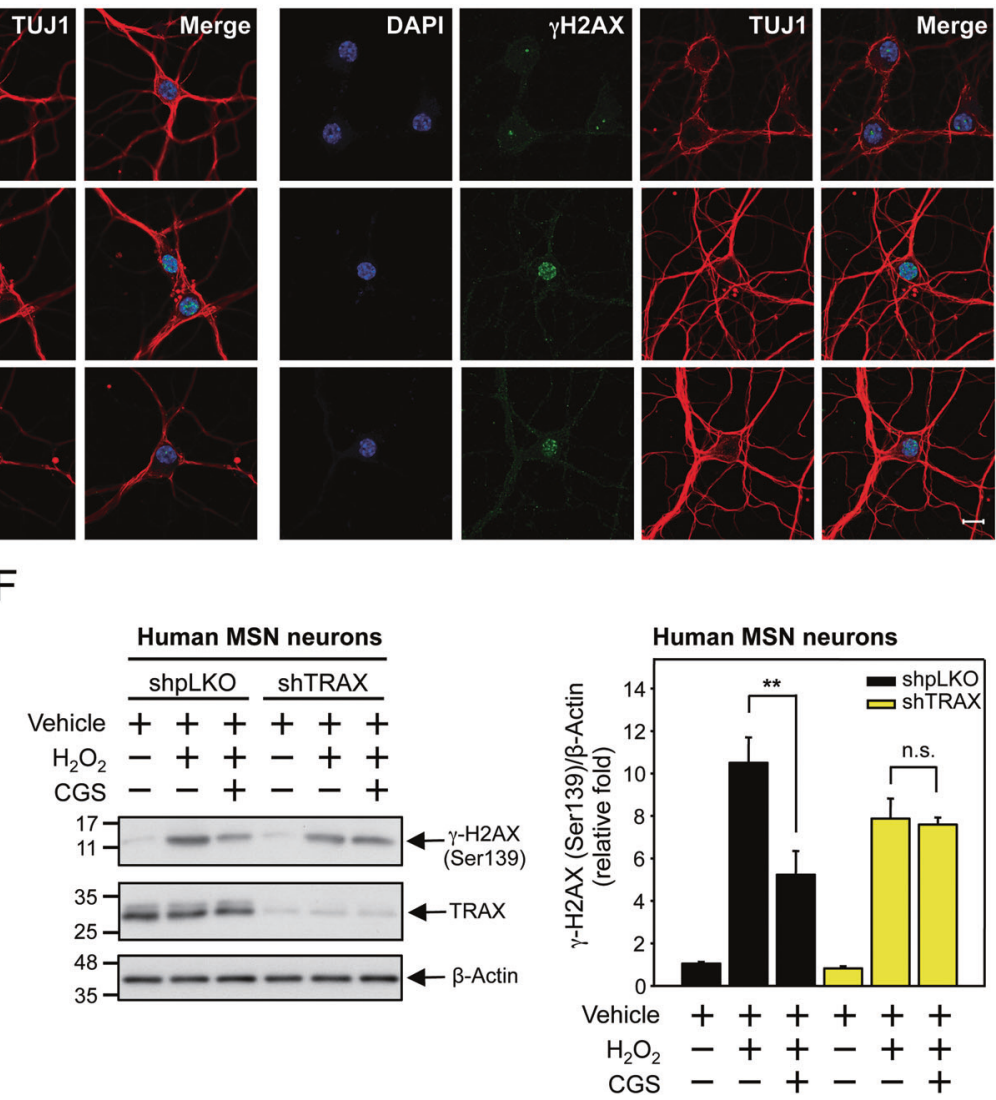
4 Fig. 2 The protective effect of an $\mathrm{A}_{2 \mathrm{~A}} \mathrm{R}$ agonist is mediated by TRAX. a-c PC12-pSuper and PC12-shTRAX cells were treated with an $\mathrm{A}_{2 \mathrm{~A}} \mathrm{R}$ agonist (CGS21680, CGS; $10 \mu \mathrm{M}$ ) or vehicle for $1 \mathrm{~h}$ to activate the $\mathrm{A}_{2 \mathrm{~A}} \mathrm{R}$ and then treated with $\mathrm{H}_{2} \mathrm{O}_{2}(100 \mu \mathrm{M})$ for $4 \mathrm{~h}$. Cells were lysed and subjected to SDS-PAGE, followed by Western blot analysis using the anti- $\gamma \mathrm{H} 2 \mathrm{AX}$, anti-TRAX and anti- $\alpha$-Tubulin antibodies as indicated. The amount of target protein was quantified and normalized to that of $\alpha$-Tubulin, the loading control. These experiments were repeated three times (a). The extent of DNA damage was analyzed via the neutral comet assay. The mean tail moment was quantified with COMETscore.v1.5 software, scale bar, $50 \mu \mathrm{m}$ (b). Apoptosis was assessed with the Annexin V apoptosis detection kit. Cells were costained with Annexin V-FITC and PI for 10 min followed by flow cytometric analysis. These experiments were repeated three times (c). d, e Primary hippocampal neurons (DIV14) from TRAX-WT and TRAX-null mice were treated with CGS $(10 \mu \mathrm{M})$ or vehicle for $1 \mathrm{~h}$ and then treated with $\mathrm{H}_{2} \mathrm{O}_{2}(100 \mu \mathrm{M})$ for $2 \mathrm{~h}$. DNA damage was assessed by determining the number of DNA foci per cell by immunofluorescence staining using the anti- $\gamma \mathrm{H} 2 \mathrm{AX}$ antibody (green) in neurons identified by a neuronal marker (TUJ1, red). The percentage of cells with $>5 \gamma \mathrm{H} 2 \mathrm{AX}$ foci per cell in at least 100 cells were determined in each condition. Scale bar, $10 \mu \mathrm{m}$. f Human MSN neurons were infected with lentivirus expressing TRAX shRNA or control shRNA for 3 days. Human MSN neurons were treated with an $\mathrm{A}_{2 \mathrm{~A}} \mathrm{R}$ agonist (CGS21680, CGS; $10 \mu \mathrm{M}$ ) or vehicle for $1 \mathrm{~h}$ to activate the $\mathrm{A}_{2 \mathrm{~A}} \mathrm{R}$ and then treated with $\mathrm{H}_{2} \mathrm{O}_{2}(100 \mu \mathrm{M})$ for $4 \mathrm{~h}$. Cells were lysed and subjected to SDS-PAGE, followed by Western blot analysis using the anti- $\gamma \mathrm{H} 2 \mathrm{AX}$, anti-TRAX and anti- $\beta$-Actin antibodies as indicated. The amount of target protein was quantified and normalized to that of $\beta$ Actin, the loading control. These experiments were repeated three times. Data are presented as the mean \pm SEM from at least three independent experiments. $* P<0.05, * * P<0.01$ compared to control

the protective effect of CGS on oxidative DNA damage (Fig. 1e), the action of CGS was mediated by the $\mathrm{A}_{2 \mathrm{~A}} \mathrm{R}$.

Because stimulation of the $A_{2 A} R$ leads to activation of the cAMP/PKA pathway, we next performed experiments to evaluate the involvement of PKA. As shown in Fig. 1e, pretreatment with a PKA inhibitor (H89) effectively reversed the protective effect of CGS. In addition, no protective effect of CGS on oxidative DNA damage was observed in a PKA-deficient PC12 cell line (A123) [44] (Fig. 1f). These findings confirmed that the protective effect of CGS on oxidative DNA damage was mediated by the $\mathrm{A}_{2 \mathrm{~A}} \mathrm{R}$ and required PKA in rodent neurons.

To investigate the role of TRAX in the protective effect of the $\mathrm{A}_{2 \mathrm{~A}} \mathrm{R}$ on oxidative DNA damage, we generated a stable cell line (termed PC12-shTRAX) that permanently expressed an shRNA against the rat TRAX (shTRAX-F, [24]) and reduced the expression of endogenous TRAX in PC12 cells (Fig. 2a). We previously showed that TRAX plays a critical role in the detection of DNA damage by directly interacting with ATM and stabilizing the Mre11Rad50-Nbs1 complex at double-strand breaks in mouse embryo fibroblasts [23]. Similarly, the lack of TRAX in the striatum of TRAX-null mice markedly hindered the ability of striatal neurons to detect the X-irradiation-induced DNA damage as monitored by the amount of $\gamma \mathrm{H} 2 \mathrm{AX}$ (Fig. S1). In line with the above findings, we found that reduction of TRAX jeopardized the ability to repair DNA damage evoked by oxidative stress and led to an impairment in detecting $\gamma \mathrm{H} 2 \mathrm{AX}$ in PC12-shTRAX cells compared to control cells (PC12-pSuper, Fig. 2a). Reduction of TRAX alone (PC12-shTRAX) did not affect the number of DSBscontaining cells, detected via the Comet assay, at the basal level and the $\mathrm{H}_{2} \mathrm{O}_{2}$-treated cells $(p=0.83$ and 0.50 , verses PC12-pSuper cells, respectively; Fig. 2b). Most importantly, down-regulation of TRAX in PC12 cells prevented the $\mathrm{A}_{2 \mathrm{~A}} \mathrm{R}$-evoked protective effect on oxidative DNA damage and apoptosis (Fig. 2a-c). Similarly, no effect of CGS on oxidative stress induced- $\gamma \mathrm{H} 2 \mathrm{AX}$ foci formation at DSBs was found in primary neurons prepared from TRAXnull mice (Fig. 2d, e). To validate this role of TRAX in human neurons, human iPSC-derived MSNs were infected with lentiviruses harboring an shRNA against human TRAX for 3 days. The endogenous level of TRAX in human neurons infected with shTRAX was significantly reduced when compared with neurons infected with a control virus (sh-pLKO, Fig. 2f). The suppression of TRAX in human MSNs also markedly reduced the CGS-evoked protective effect on oxidative damage (Fig. 2f). Taken together, these findings suggest that TRAX is required for the protective effect of the $A_{2 A} R$ on oxidative DNA damage in both human and rodent neurons.

\section{TRAX contributes to the ATM/DNA-PK-mediated NHEJ pathway evoked by $A_{2 A} R$ activation}

TRAX has been implicated in DNA repair because it interacts with an activator (i.e., C1D) of DNA-PK, a major enzyme responsible for NHEJ [8], in response to stresses that cause DSBs [22]. To evaluate whether the stimulation of the $\mathrm{A}_{2 \mathrm{~A}} \mathrm{R}$ activated DNA-PK $\mathrm{CS}, \mathrm{PC} 12$ cells were treated with $\mathrm{H}_{2} \mathrm{O}_{2}$ to elevate oxidative stress for $1-4 \mathrm{~h}$ in the absence or presence of pretreatment with CGS. The activation of DNA-PK $\mathrm{CS}_{\mathrm{C}}$ was evaluated by determining the phosphorylation level of DNA-PK $\mathrm{CS}_{\text {at }} \mathrm{Thr}^{2609}$ [8] by Western blot analysis. Our results showed that CGS pre-

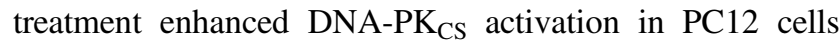
under the conditions tested (Fig. 3a). Down-regulation of TRAX markedly removed the activation/phosphorylation of DNA-PK ${ }_{\mathrm{CS}}$ when compared to PC12-pSuper cells (Fig. 3b), suggesting that stimulation of the $\mathrm{A}_{2 \mathrm{~A}} \mathrm{R}$ led to the activation

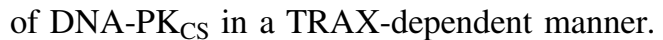

Surprisingly, the down-regulation of C1D in PC12 cells did not affect the protective effect of the $\mathrm{A}_{2 \mathrm{~A}} \mathrm{R}$ on oxidative DNA damage (Fig. S2), suggesting that C1D was not involved. Because we previously demonstrated that TRAX directly interacts with ATM [23] and an earlier study showed that ATM is required for the activation/phosphorylation of DNA-PKes at $\mathrm{Thr}^{2609}$ [45], we went on to 
determine whether ATM is involved in the activation of DNA-PK $\mathrm{CS}_{\mathrm{C}}$ during $\mathrm{A}_{2 \mathrm{~A}} \mathrm{R}$ activation. Treatment with the ATM inhibitor KU55933 effectively abolished the CGSmediated enhancement of DNA-PK ${ }_{\mathrm{CS}}$ activity (Fig. 3c), suggesting that ATM functions upstream of DNA-PK $\mathrm{CS}_{\mathrm{CS}}$ during the activation of the $\mathrm{A}_{2 \mathrm{~A}} \mathrm{R}$ to facilitate DNA repair.

Because DNA-PK $\mathrm{CS}_{\mathrm{CS}}$ is the major enzyme that mediates NHEJ [8], we next conducted experiments to determine
A

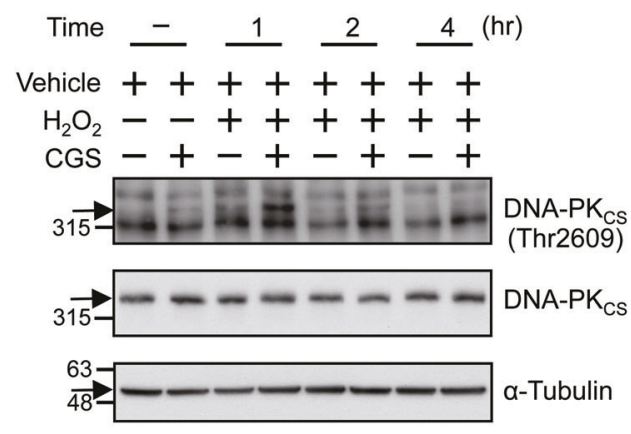

B

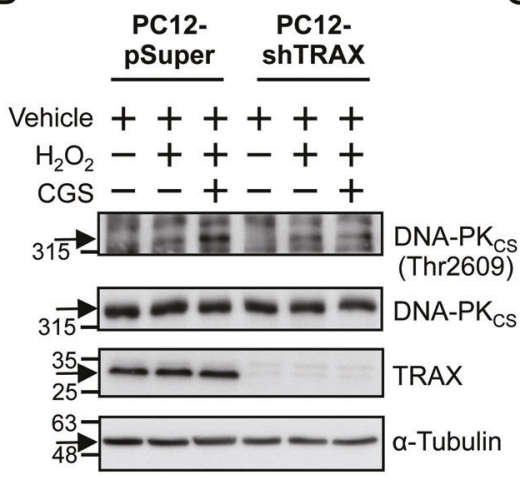

C

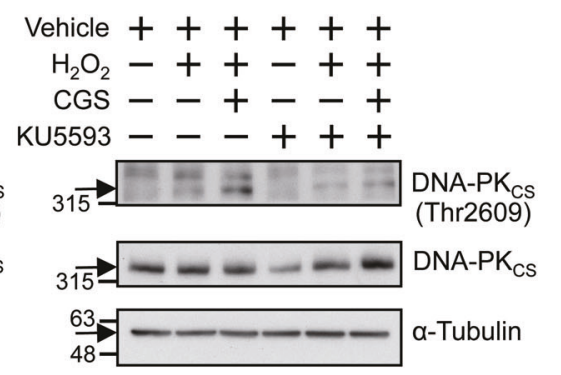

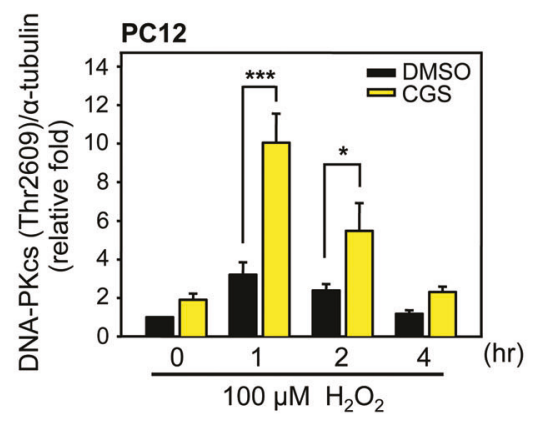

D

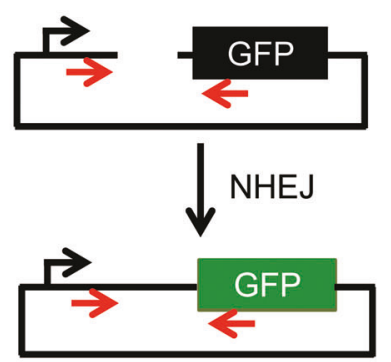

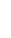
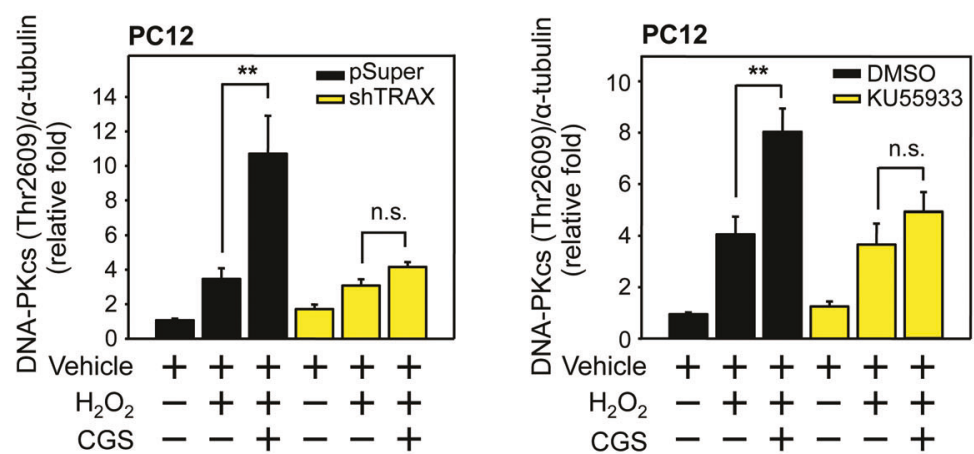

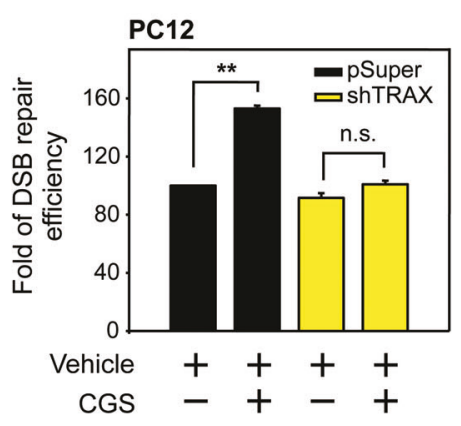

Fig. 3 TRAX and ATM contribute to the DNA-PK-mediated NHEJ pathway evoked by $\mathrm{A}_{2 \mathrm{~A}} \mathrm{R}$ activation. a PC12 cells were treated with an $\mathrm{A}_{2 \mathrm{~A}} \mathrm{R}$ agonist (CGS21680, CGS; $10 \mu \mathrm{M}$ ) or vehicle for $1 \mathrm{~h}$. Following the treatment, cells were treated with $\mathrm{H}_{2} \mathrm{O}_{2}(100 \mu \mathrm{M})$ for the indicated time periods. Cells were lysed and analyzed by immunoblotting with anti-DNA-PKcs T2609, anti-DNA-PKcs and anti- $\alpha$-Tubulin antibodies. The amount of target protein was quantified and normalized to that of $\alpha$ Tubulin, the loading control. These experiments were repeated three times. b PC12-pSuper and PC12-shTRAX cells were treated with CGS $(10 \mu \mathrm{M})$ for $1 \mathrm{~h}$ and treated with $\mathrm{H}_{2} \mathrm{O}_{2}(100 \mu \mathrm{M})$ for $1 \mathrm{~h}$. Cells were lysed and analyzed by immunoblotting with anti-DNA-PKcs T2609, anti-DNA-PKcs, anti-TRAX and anti- $\alpha$-Tubulin antibodies. The amount of target protein was quantified and normalized to that of $\alpha$ Tubulin, the loading control. These experiments were repeated three times. c PC12 cells were treated with an inhibitor of ATM (KU55933; $10 \mu \mathrm{M})$ or vehicle for $30 \mathrm{~min}$ and then treated with CGS $(10 \mu \mathrm{M})$ or vehicle for $1 \mathrm{~h}$ to activate the $\mathrm{A}_{2 \mathrm{~A}} \mathrm{R}$, followed by the addition of $\mathrm{H}_{2} \mathrm{O}_{2}$ $(100 \mu \mathrm{M})$ for $1 \mathrm{~h}$. Cells were lysed and subjected to SDS-PAGE, followed by Western blot analysis using the anti-DNA-PKcs T2609, antiDNA-PKcs and anti- $\alpha$-Tubulin antibodies as indicated. The amount of target protein was quantified and normalized to that of $\alpha$-Tubulin, the loading control. These experiments were repeated three times. d Schematic illustration of the NHEJ assay in vivo. A single DSB was generated in this plasmid substrate pEGFP-C3 with NheI to cut between the promoter and the GFP gene. Linearized plasmids and the circular pDsRed-monomer-C1 as the internal control for transfection efficiency were cotransfected into the PC12-pSuper cells and PC12-shTRAX cells. The region of the forward primer binding site is in the promoter and the reverse primer binding site is in the GFP gene. After transfection for 2 days, cells were collected for qPCR. Data are shown as the mean \pm SEM from three independent experiments. $* P<0.05$, $* * P<$ $0.01, * * * P<0.001$ compared to control 
A

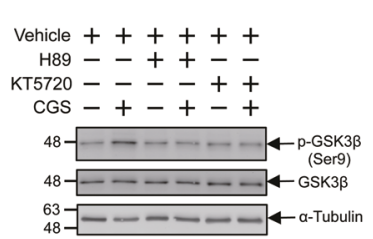

B

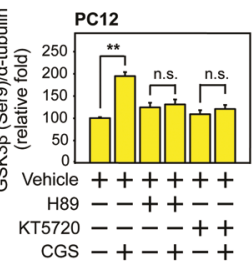

D

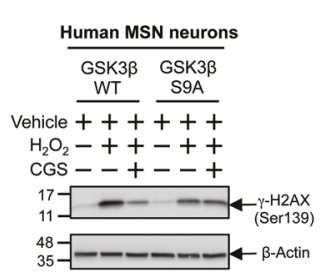

F
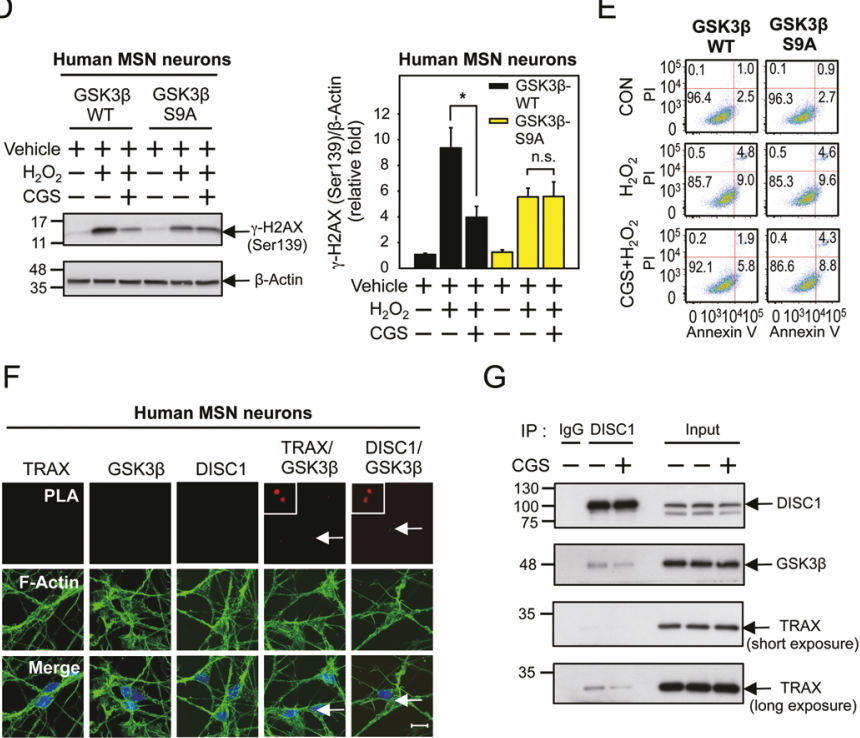

G

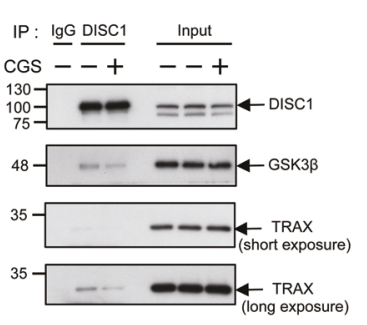

$\mathrm{H}$

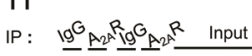
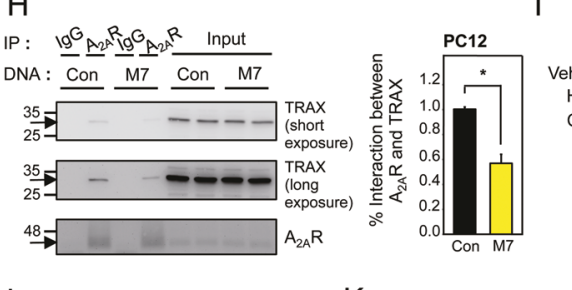

J
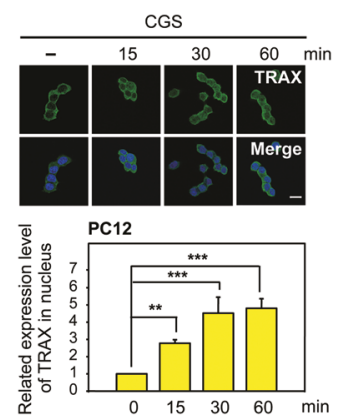

K

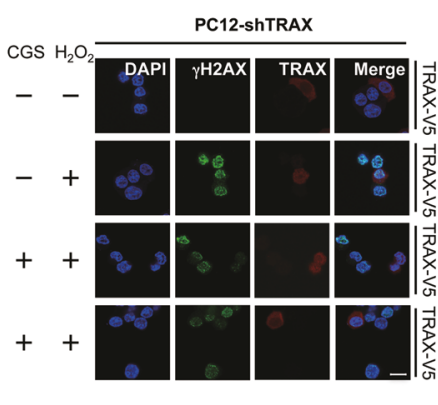

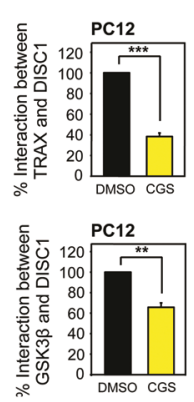
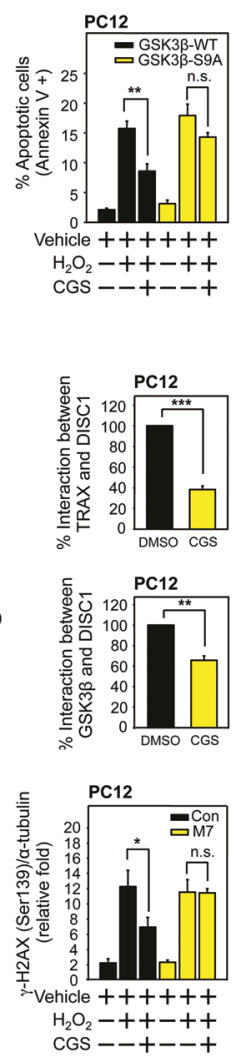

PC12-shTRAX

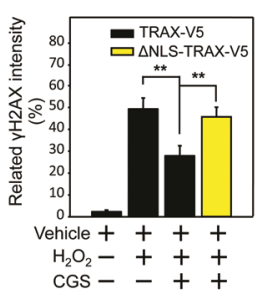


Fig. 4 The TRAX/DISC1/GSK3 $\beta$ (TDG) complex is involved in the protective effect of an $\mathrm{A}_{2 \mathrm{~A}} \mathrm{R}$ agonist. a, b PC12 cells were treated with an inhibitor of protein kinase A (H89; $10 \mu \mathrm{M}$ and KT5720; $10 \mu \mathrm{M})$ or vehicle for $30 \mathrm{~min}$ and then treated with CGS $(10 \mu \mathrm{M})$ or vehicle for 1 $\mathrm{h}(\mathbf{a})$ and $8 \mathrm{~h}$ (b). Cells were lysed and subjected to SDS-PAGE, followed by Western blot analysis using the anti-GSK3 $\beta$ Ser9, antiGSK3 $\beta$, anti- $\beta$-catenin and anti- $\alpha$-Tubulin antibodies as indicated. The amount of target protein was quantified and normalized to that of $\alpha$ Tubulin, the loading control. These experiments were repeated three times. c-e In PC12 cells and human MSN neurons, cells were infected with lentivirus expressing GSK3 $\beta$ or a constitutively active GSK3 $\beta$ mutant (GSK3 $\beta-S 9 A)$ for 3 days. Cells were treated with an $A_{2 A} R$ agonist (CGS21680, CGS; $10 \mu \mathrm{M}$ ) or vehicle for $1 \mathrm{~h}$ to activate the $\mathrm{A}_{2 \mathrm{~A}} \mathrm{R}$ and then treated with $\mathrm{H}_{2} \mathrm{O}_{2}(100 \mu \mathrm{M})$ for $4 \mathrm{~h}$. Cells were lysed and subjected to SDS-PAGE, followed by Western blot analysis using the anti- $\gamma \mathrm{H} 2 \mathrm{AX}$, anti- $\alpha$-Tubulin and anti- $\beta$-Actin antibodies as indicated. The amount of target protein was quantified and normalized to that of $\alpha$-Tubulin or $\beta$-Actin, the loading controls. These experiments were repeated three times $(\mathbf{c}, \mathbf{d})$. Apoptosis was assessed by co-staining with Annexin V-Cy5 and PI for 10 min followed by flow cytometric analysis (e). f Protein-protein interactions were monitored by the proximity ligation assay [31] using the corresponding antibodies as described in the Methods section [31]. Each red dot represents the detection of protein-protein interaction. Scale bar, $10 \mu \mathrm{m}$. g PC12 cells were treated with an $\mathrm{A}_{2 \mathrm{~A}} \mathrm{R}$ agonist (CGS21680, CGS; $10 \mu \mathrm{M}$ ) or vehicle for $1 \mathrm{~h}$. Cells were lysed, subjected to immunoprecipitation with anti-DISC1 and immunoblotted with anti-DISC1, anti-TRAX and anti-GSK3 $\beta$ antibodies. The amount of target protein was quantified and normalized to that of the input. These experiments were repeated three times. h PC12 cells were infected with the lentivirus expressing $A_{2 A} R_{253-410}$-Flag (M7) for 3 days. Cells were lysed, subjected to immunoprecipitation with an anti- $\mathrm{A}_{2 \mathrm{~A}} \mathrm{R}$ antibody or a control $\mathrm{IgG}$, followed by Western blot analysis using the indicated antibody. The amount of TRAX that interacted with $\mathrm{A}_{2 \mathrm{~A}} \mathrm{R}$ was quantified and normalized to that of the input. These experiments were repeated three times. i PC12 cells were infected with lentivirus expressing $A_{2 A} R_{253-410}$-Flag for 3 days. Cells were treated with CGS $(10 \mu \mathrm{M})$ or vehicle for $1 \mathrm{~h}$ to activate the $\mathrm{A}_{2 \mathrm{~A}} \mathrm{R}$ and then treated with $\mathrm{H}_{2} \mathrm{O}_{2}(100 \mu \mathrm{M})$ for $4 \mathrm{~h}$. Cells were lysed and subjected to SDS-PAGE, followed by Western blot analysis using the anti- $\gamma \mathrm{H} 2 \mathrm{AX}$, anti-Flag and anti- $\alpha$-Tubulin antibodies as indicated. The amount of target protein was quantified and normalized to that of $\alpha$ Tubulin, the loading controls. These experiments were repeated three times. j PC12 cells were treated with CGS $(10 \mu \mathrm{M})$ during the indicated time period. Cells were subjected to immunostaining with an anti-TRAX antibody (Green). Scale bar, $10 \mu \mathrm{m}$. k PC12-shTRAX cells were transfected with TRAX-V5 and $\triangle$ NLS TRAX-V5 plasmids. Cells were treated with CGS $(10 \mu \mathrm{M})$ or vehicle for $1 \mathrm{~h}$ to activate the $\mathrm{A}_{2 \mathrm{~A}} \mathrm{R}$ and then treated with $\mathrm{H}_{2} \mathrm{O}_{2}(100 \mu \mathrm{M})$ for $4 \mathrm{~h}$. Cells were subjected to immunostaining with anti- $\gamma \mathrm{H} 2 \mathrm{AX}$ (Green) and anti-V5 (Red) antibodies. Scale bar, $10 \mu \mathrm{m}$. Data are presented as the mean \pm SEM from at least three independent experiments. $* P<0.05$, $* * P<$ $0.01, * * * P<0.001$ compared to control

whether the activation of the $\mathrm{A}_{2 \mathrm{~A}} \mathrm{R}$ enhanced the activity of the NHEJ pathway. PC12-shTRAX and PC12-pSuper cells were transfected with a linearized plasmid (pEGFP-C3) that is to be repaired through NHEJ. The amount of the repaired, circular form of pEGFP-C3 was quantified by qPCR. As shown in Fig. 3d, CGS treatment significantly enhanced the activity of the NHEJ pathway in PC12-pSuper cells, but not PC12-shTRAX cells. Collectively, these findings suggest the activation of the $\mathrm{A}_{2 \mathrm{~A}} \mathrm{R}$ using CGSfacilitated DNA repair upon oxidative stress via a TRAX/ATM/DNA-PK-mediated NHEJ pathway.

\section{GSK3 $\beta$ binds with DISC1 and TRAX and negatively regulates the TRAX-mediated DNA repair during oxidative DNA damage}

Because GSK3 $\beta$ has been negatively implicated in neuroprotection and DNA-PK-mediated repair $[42,46]$ and $A_{2 A} R$ activation leads to the serine phosphorylation and inhibition of GSK3 activity [47, 48], we next evaluated whether GSK3 $\beta$ is involved in DNA-PK-mediated DNA repair during $\mathrm{A}_{2 \mathrm{~A}} \mathrm{R}$ stimulation. As shown in Fig. 4a, stimulation of the $A_{2 A} R$ by CGS enhanced the phosphorylation of GSK3 $\beta$ at Ser $^{9}$, which suppressed GSK3 $\beta$ activity. No inhibition/ phosphorylation of GSK3 $\beta$ was observed in the presence of PKA inhibitors (H89 or KT5720, Fig. 4a). Because previous studies have shown that mitogen-activated protein kinase (MAPK) and phosphatidylinositol-3 kinase (PI3K) may function upstream of GSK3 $\beta$ [49], we next tested whether these two kinases are involved in the regulation of GSK3 $\beta$ in PC12 cells. As shown in Figure S3A, pretreatment of PC12 cells with a MAPK inhibitor (UO126, $10 \mu \mathrm{M})$ or a PI3K inhibitor (LY294002, $20 \mu \mathrm{M}$ ) did not affect the $\mathrm{A}_{2 \mathrm{~A}} \mathrm{R}$ mediated inhibition of GSK3 $\beta$. Collectively, these results demonstrated that $A_{2 A} R$ stimulation reduced GSK3 $\beta$ activity via a pathway that requires activation of PKA, but not MAPK or PI3K.

In addition to assessing the GSK3 $\beta$ activity by determining the level of GSK $3 \beta-$ Ser $^{9}$ phosphorylation, we also evaluated a downstream target of GSK3 $\beta$ to validate the activation of GSK3 $\beta$. Specifically, expression of $\beta$-catenin is negatively regulated by GSK3 $\beta$ [20]. Consistent with the inhibition of GSK3 $\beta$ by $A_{2 A} R$, stimulation of $A_{2 A} R$ increased the level of $\beta$-catenin, and this effect was reversed by two PKA inhibitors (H89 and KT5760; Fig. 4b). PKA assay revealed that stimulation of $\mathrm{A}_{2 \mathrm{~A}} \mathrm{R}$ enhanced PKA activity, which was blocked by PKA inhibitors (Fig. S3B). Taken together, these results confirmed that activation of $\mathrm{A}_{2 \mathrm{~A}} \mathrm{R}$ inhibited GSK3 $\beta$ through a PKA-dependent pathway.

To assess whether GSK3 $\beta$ plays an important role in DNA repair, we created a constitutively active GSK3 $\beta$ mutant (GSK3 $\beta$-S9A) [50]. The overexpression of a GSK3ß-S9A in PC12 cells (Fig. 4c) and in human MSNs derived from iPSCs (Fig. 4d) abolished the protective effect of CGS on oxidative DNA damage assessed by the level of $\gamma \mathrm{H} 2 \mathrm{AX}$. In addition, the overexpression of GSK3 $\beta$-S9A eliminated the protective effect of CGS on apoptosis evoked by oxidative DNA damage (Fig. 4e), confirming the importance of GSK3 $\beta$ inhibition in the protective effect of the $\mathrm{A}_{2 \mathrm{~A}} \mathrm{R}$ in $\mathrm{PC} 12$ cells.

Previous studies suggest that GSK3 $\beta$ physically interacts with DISC1 [19, 51, 52], an important scaffold protein that 
A

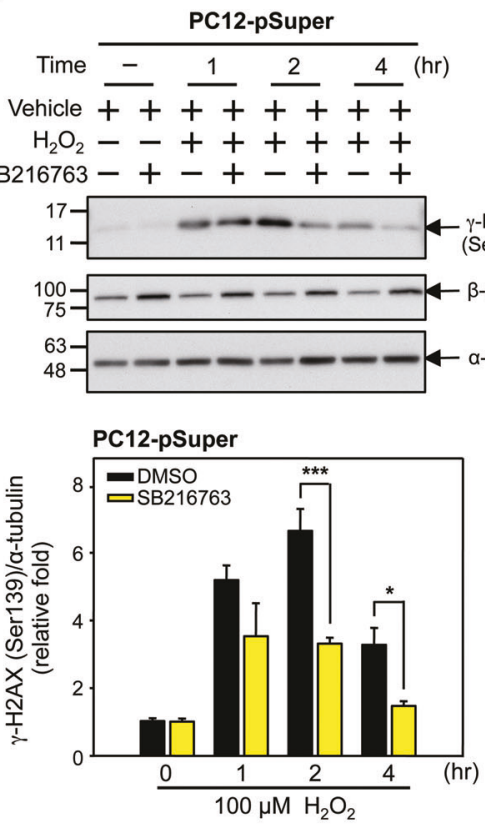

B

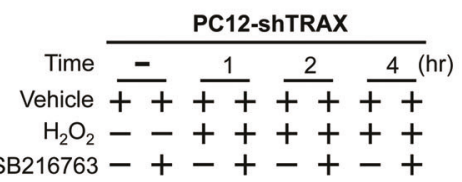
B216763

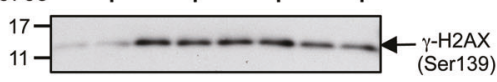

${ }_{75}^{100}=----\infty-\beta$-catenin 63- $--\ldots-\infty-\infty-$-Tubulin

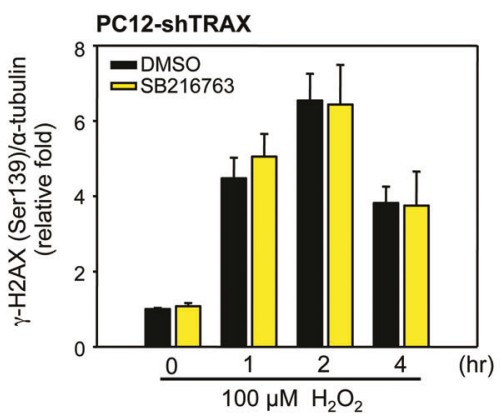

C

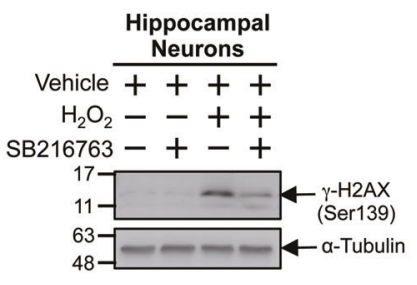

D
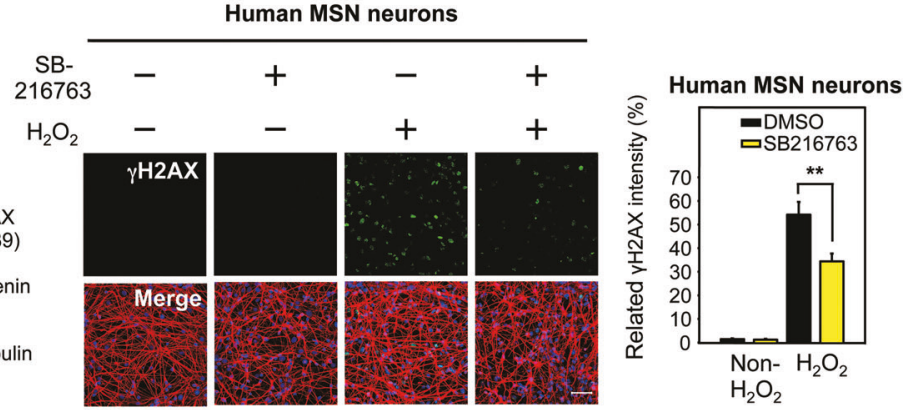

E
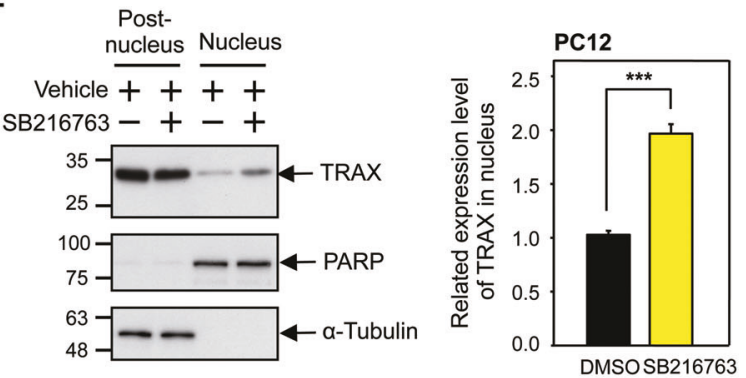

F

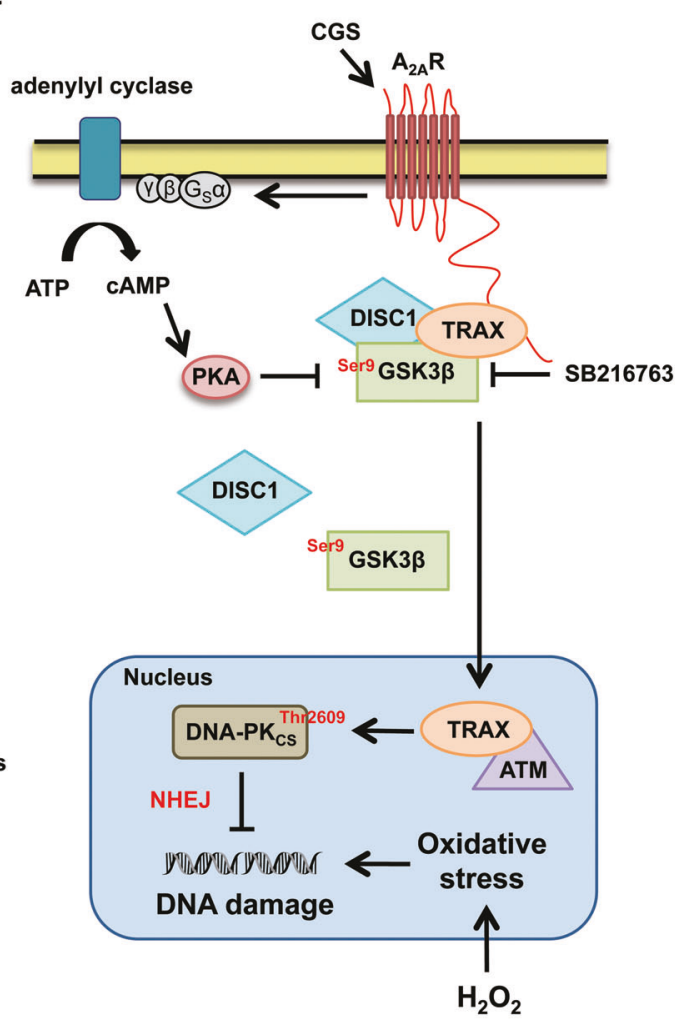


4 Fig. 5 Inhibition of GSK3 $\beta$ enables TRAX-dependent DNA repair. a, b PC12-pSuper and PC12-shTRAX cells were treated with a GSK3 $\beta$ inhibitor (SB216763, $10 \mu \mathrm{M}$ ) or vehicle for 2 days. After the abovementioned treatment, cells were subjected to $\mathrm{H}_{2} \mathrm{O}_{2}(100 \mu \mathrm{M})$ for $1-4 \mathrm{~h}$ as indicated. The levels of $\gamma \mathrm{H} 2 \mathrm{AX}, \beta$-catenin, and $\alpha$-Tubulin (a loading control) were evaluated by Western blot analysis using the indicated antibodies. The relative amounts of target proteins were quantified and normalized to that of $\alpha$-Tubulin, the loading control. These experiments were repeated three times. c Primary hippocampal neurons (DIV14) harvested from wild-type B6/C57 mice were treated with SB216763 $(10 \mu \mathrm{M})$ or vehicle for 1 day and then treated with $\mathrm{H}_{2} \mathrm{O}_{2}(100 \mu \mathrm{M})$ for $2 \mathrm{~h}$. Cells were lysed and subjected to SDS-PAGE, followed by Western blot analysis using the anti- $\gamma \mathrm{H} 2 \mathrm{AX}$ and anti- $\alpha-$ Tubulin antibodies, as indicated. The amount of target protein was quantified and normalized to that of $\alpha$-Tubulin, the loading control. These experiments were repeated three times. d Human iPSCs-derived MSN neurons were treated with SB216763 $(10 \mu \mathrm{M})$ or vehicle for 1 day and then treated with $\mathrm{H}_{2} \mathrm{O}_{2}(100 \mu \mathrm{M})$ for $4 \mathrm{~h}$. DNA damage was assessed by determining the intensity of the DNA damage marker $\gamma \mathrm{H} 2 \mathrm{AX}$ by immunofluorescence staining using the anti- $\gamma \mathrm{H} 2 \mathrm{AX}$ antibody (green) in neurons identified by a neuronal marker (TUJ1, red). Scale bar, $50 \mu \mathrm{m}$. e PC12 cells were treated with a GSK3 $\beta$ inhibitor (SB216763, $10 \mu \mathrm{M})$ or vehicle for 2 days and nuclear and cytosolic fractions were isolated. Cells were lysed and subjected to SDS-PAGE, followed by Western blot analysis using the anti-TRAX, anti- $\alpha-$ Tubulin and anti-PARP antibodies as indicated. The amount of target protein was quantified and normalized to that of $\alpha$-Tubulin or PARP, the loading controls for post-nucleus and nucleus fractions, respectively. These experiments were repeated three times. The data are presented as the mean \pm SEM from at least three independent experiments $0 . * P<0.05, * * P<0.01, * * * P<0.001$ compared to control. f A schematic representation showing that TRAX interacts with the $\mathrm{A}_{2 \mathrm{~A}} \mathrm{R}$ and forms complexes with GSK3 $\beta$ and DISC1 at the resting stage. Inhibition of GSK3 $\beta$ by either the activation of an $A_{2 A} R /$ PKA-dependent pathway or a GSK3 $\beta$-specific inhibitor (SB216763) would release TRAX from the complex to facilitate the ATM/DNAPK- dependent NHEJ in the nuclei

functionally interacts with TRAX [21]; we therefore evaluated whether GSK3 $\beta$ forms a complex with DISC1 and TRAX. HEK293T cells were transfected with expression constructs of V5-tagged TRAX (TRAX-V5), Myc-tagged GSK3 $\beta$ (GSK3 $\beta$-Myc) and Flag-tagged DISC1 (DISC1Flag) for $48 \mathrm{~h}$, and subjected to immunoprecipitation. Our results showed that both DISC1-Flag and GSK3 $\beta$-Myc existed in the immunocomplex with TRAX-V5 (Fig. S4A). Similarly, IP of TRAX successfully pulled down endogenous GSK3 $\beta$ and DISC1 from rat brains (Fig. S4B) and primary neurons (Fig. S4C). By the in situ proximity ligation assay, we also observed the interaction of GSK3 $\beta /$ TRAX and GSK3 $3 /$ DISC1 in human MSN cells derived from iPSCs (Fig. 4f), supporting the idea that the TRAX/ DISC1/GSK3 $\beta$ complex might exist in these cells.

Given that TRAX is an interacting protein of the $\mathrm{A}_{2 \mathrm{~A}} \mathrm{R}$ [25], we further examined whether the interaction among TRAX, DISC1 and GSK3 $\beta$ was regulated by $\mathrm{A}_{2 \mathrm{~A}} \mathrm{R}$ activation. The stimulation of the $\mathrm{A}_{2 \mathrm{~A}} \mathrm{R}$ using CGS significantly reduced the complex formation of TRAX, DISC1 and GSK3 $\beta$ in PC12 cells (Fig. 4g and S4D). The importance of the $A_{2 A} R$ was further evaluated by the overexpression of
$\mathrm{A}_{2 \mathrm{~A}} \mathrm{R}_{253-410}$ (designated M7) [25], a DNA fragment encoding the 7th transmembrane domain plus the Cterminus of the $\mathrm{A}_{2 \mathrm{~A}} \mathrm{R}$. Of note, the C-terminus of the $A_{2 A} R$ is the binding domain for TRAX [25]. Overexpression of $\mathrm{M} 7$ in $\mathrm{PC} 12$ cells reduced the interaction of $\mathrm{A}_{2 \mathrm{~A}} \mathrm{R}$ and TRAX (Fig. 4h). As shown in Fig. 4i, the expression of M7 in PC12 cells reversed the CGS-mediated rescue of oxidative DNA damage as assessed by the levels of $\gamma \mathrm{H} 2 \mathrm{AX}$. Immunofluorescence analysis further demonstrated that stimulation of the $\mathrm{A}_{2 \mathrm{~A}} \mathrm{R}$ by CGS enhanced the levels of TRAX (Fig. 4j), but not those of GSK $3 \beta$ or DISC1 (Fig. S5), in the nuclei of PC12 cells. While the overexpression of wild-type (WT) TRAX-V5 in PC12 cells with low TRAX (i.e., PC12-shTRAX) rescued the $\mathrm{A}_{2 \mathrm{~A}} \mathrm{R}$ mediated DNA repair during oxidative stress, a TRAX variant (designated $\triangle \mathrm{NLS}-\mathrm{TRAX}-\mathrm{V} 5$ ) that lacked the nuclear localization signal (NLS) produced no effect (Fig. 4k). TRAX thus appeared to execute its effect on DNA repair in nuclei.

Our findings collectively suggest that TRAX, DISC 1 and GSK3 $\beta$ form complexes that play a critical role in the regulation of repair of oxidative DNA damage. Stimulation of the $\mathrm{A}_{2 \mathrm{~A}} \mathrm{R}$ disrupted the TRAX/DISC1/GSK3 $\beta$ complex and allowed TRAX to enter nuclei for DNA repair.

\section{GSK3 $\beta$ blockade enables TRAX to mediate DNA repair during oxidative DNA damage}

Our findings led us to hypothesize that inhibition of GSK3 $\beta$ might result in the disassembly of its interaction with DISC1 and TRAX and subsequently release TRAX to facilitate DNA repair. To test this hypothesis, PC12 cells were treated with the indicated GSK3 $\beta$ inhibitor (SB216763, $10 \mu \mathrm{M}$; Fig. 5a) to suppress GSK3 $\beta$ activity before the exposure to oxidative stress $\left(\mathrm{H}_{2} \mathrm{O}_{2}\right)$ for $1-4 \mathrm{~h}$ as indicated. Treatment with a GSK3 $\beta$ inhibitor significantly enhanced the expression level of a downstream target (i.e., $\beta$-catenin, [20]) of GSK3 $\beta$, demonstrating the effective blockade of GSK3 $\beta$. Most intriguingly, although the initial oxidative DNA damage assessed by the amounts of $\gamma \mathrm{H} 2 \mathrm{AX}$ in the first hour of $\mathrm{H}_{2} \mathrm{O}_{2}$ treatment was similar, the levels of $\gamma \mathrm{H} 2 \mathrm{AX}$ in PC12-pSuper cells treated with GSK3 $\beta$ inhibitors were much lower than those of the vehicle-treated cells in the later time course ( 2 and $4 \mathrm{~h}$; Fig. 5a).

Similarly, inhibition of GSK3 $\beta$ by SB216763 protects cells from oxidative stress-induced DNA damage in primary neurons and iPSCs-derived human MSN cells (Fig. 5c, d). Consistent with our hypothesis that TRAX plays a critical role in this DNA repair process, a GSK3 $\beta$ inhibitor SB216763 exerted no effect on the repair of DNA damage in PC12-shTRAX cells that had low levels of TRAX (Fig. 5b). Similar to the effect of CGS (Fig. 4j), inhibition of GSK3 $\beta$ by SB216763 also increased the level of TRAX in 
the nucleus (Fig. 5e), supporting that TRAX may function in the nuclei. These results collectively suggested that blockade of GSK3 $\beta$ facilitates the TRAX-mediated DNA repair process.

\section{Discussion}

We have previously reported that TRAX plays a critical role in the $\mathrm{ATM} / \gamma \mathrm{H} 2 \mathrm{AX}$-mediated DNA repair pathway by directly interacting with ATM at DSBs in the nuclei [23]. In the present study, we provide evidence to demonstrate that TRAX formed complexes with GSK3 $\beta$ and DISC1 at the resting stage (Fig. 4 and S4). Inhibition of GSK3 $\beta$ by either the activation of an $\mathrm{A}_{2 \mathrm{~A}} \mathrm{R} / \mathrm{PKA}$-dependent pathway (Figs. 4a, $\mathrm{b}$ and S3B) or a GSK3ß-specific inhibitor (SB216763; Fig. 5a) would release TRAX from the complex to facilitate the ATM/DNA-PK- dependent NHEJ in the nuclei (Figs. $4 \mathrm{j}$ and 5e). The function of TRAX in DNA repair was confirmed in a rat neuron-like cell line ( $\mathrm{PC} 12$ cells), primary mouse hippocampal neurons, and human MSN cells derived from iPSCs (Fig. 2), suggesting that facilitation of the repair for oxidative DNA damage is a conserved function of TRAX. Because a deficiency in DNA repair has been implicated in many mental disorders (including bipolar disorder and schizophrenia) [2,3], our findings provide an intriguing explanation for the association between the human TRAX gene and these mental illnesses [15, 16, 53].

TRAX is a multi-functional scaffold protein that regulates various cellular activities by interacting with many proteins for a growing list of different functions, including proliferation [54], trafficking of brain-derived neurotrophic factor (BDNF) mRNA [55], production of RNAi [10], neuritogenesis [25], and DNA repair [23]. In the present study, we report that DISC1 and GSK3 $\beta$ are two additional interacting proteins of TRAX. In addition to functionally associating with DISC1 [21], we found that TRAX also physically interacts with DISC1 (Fig. 4 and S4), a risk gene for schizophrenia. In fact, the human DISC1 and TRAX genes are located nearby at 1q42. This DISC1/TRAX locus is associated with mental illnesses, including schizophrenia $[15,16]$. Mice lacking TRAX (TRAX-null) showed abnormal behaviors as evaluated by the open-field and the elevated plus-maze tests (data not shown). In addition, DISC1 mutant mice that lack exons 2 and 3 of the DISC1 gene also showed similar behaviors to those of TRAX-null mice [56]. Importantly, the association of TRAX with DISC 1 and GSK $3 \beta$ is regulated by the activity of GSK3 $\beta$. The inhibition of GSK3 $\beta$ via various approaches allowed TRAX to mediate the repair process of oxidative DNA damage (Figs. 4, 5). We hypothesized that the TRAX/ DISC1/GSK $3 \beta$ complex might serve as a tightly controlled unit and could be regulated by stimuli that inhibit GSK3 $\beta$ and subsequently release TRAX for the subsequent action (s). It is of interest to evaluate whether TRAX contributes to other known actions of GSK3 $\beta$ or/and DISC 1 in the future.

Lithium, an inhibitor of GSK3 $\beta$, is a widely used mood stabilizer in the treatment of many mental diseases, notably bipolar disorder [57]. Although the molecular mechanism underlying its clinical effectiveness remains largely elusive, the inhibition of GSK $3 \beta$ has been implicated in multiple actions of lithium [58, 59]. Most interestingly, lithium can also be used to treat ethanol toxicity and ischemia [60, 61], in which high oxidative stresses occur. The observations in the present study are consistent with those studies and suggest that lithium is neuroprotective against stresses that cause DNA damage. For example, lithium enhances DNA-PK-mediated DNA repair in irradiated hippocampal neurons [42]. More recently, lithium has been shown to protect retinal neurocytes from ischemia-induced damage by the up-regulation of DNA ligase IV, a key NHEJ ligase, via a pathway that requires nuclear respiratory factor 1 (Nrf1) and the activation of cyclic AMP-response element binding protein-1 (p-CREB1) [62]. The results of our study revealed a new component, TRAX, which mediates the protective effect of a GSK3 $\beta$ inhibitor on oxidative DNA damage in neurons (Fig. 5). In addition to mental disorders and neuronal traumas, oxidative DNA damage or inferior DNA repair systems have also been reported in neurodegenerative diseases [9, 63-66]. For example, multiple reports suggest that DISC1 is a candidate gene for Alzheimer's disease [67]. Dysregulations of DISC1 and GSK3 $\beta$ are part of the Huntington's disease (HD) pathogenesis [68, 69]. Lithium, which blocks GSK3 $\beta$ and regulates other signaling pathways, has also been considered one of the beneficial reagents for the amelioration of degenerative diseases [57, 70]. Given the clinical importance of lithium, further investigations are warranted to assess the potential involvement of TRAX/DISC1/GSK3 $\beta$ in various mental diseases, brain traumas, and neurodegenerative diseases.

Beyond the blockade of GSK3 $\beta$ directly using SB216763, our study demonstrated that stimulation of the $\mathrm{A}_{2 \mathrm{~A}} \mathrm{R}$, an interacting protein of TRAX, activated PKA that inhibited GSK3 $\beta$ and subsequently freed TRAX to facilitate the ATM/DNA-PK- mediated NHEJ pathway in the nuclei (Figs. 4, 5f). Stimulation of the $\mathrm{A}_{2 \mathrm{~A}} \mathrm{R}$ might promote DNA repair in neurons and restore neuronal functions. Consistent with this hypothesis, several approaches have been explored for adenosine augmentation, which may result in the activation of adenosine receptors and ameliorate the symptoms of schizophrenia [28, 29]. Accumulated evidence suggests that adenosine contributes to neurodevelopmental processes, which have been implicated in schizophrenia [26]. Thus, it is possible that adenosine augmentation not only can be used as a treatment for schizophrenia but also prevent the genesis of schizophrenia [26, 27]. Our results 
provide potential mechanistic insights into the role of adenosine and $\mathrm{A}_{2 \mathrm{~A}} \mathrm{R}$ in schizophrenia and other mental disorders associated with inferior DNA repair [1-3].

Another interesting aspect is the regulation of the TRAX/ $A_{2 A} R$ complex. Our results suggest that inhibition of GSK3 $\beta$ may lead to dissociation of TRAX from $A_{2 A} R$. Immunoprecipitation of TRAX effectively pulled down $\mathrm{A}_{2 \mathrm{~A}} \mathrm{R}$ from detergent-soluble fractions of PC12 cells. Treatment with SB216762 markedly reduced the amount of $\mathrm{A}_{2 \mathrm{~A}} \mathrm{R}$ existing in the TRAX-immunocomplex (Fig. S6A-E), indicating that the interaction between $A_{2 A} R$ and TRAX was also regulated by GSK3 $\beta$. Because stimulation of $\mathrm{A}_{2 \mathrm{~A}} \mathrm{R}$ also suppresses GSK3 $\beta$ (Fig. 4), TRAX can be released not just from DISC1 and GSK3 $\beta$ but also from $\mathrm{A}_{2 \mathrm{~A}} \mathrm{R}$ during $\mathrm{A}_{2 \mathrm{~A}} \mathrm{R}$ stimulation. This would explain why stimulation of $\mathrm{A}_{2 \mathrm{~A}} \mathrm{R}$ by CGS enhanced the level of TRAX in the nuclei of PC12 cells (Fig. 4j) and support our hypothesis that TRAX mediates its function in DNA repair in nuclei. Of note, although the level of TRAX and $A_{2 A} R$ were not altered by treatment with SB216762, the amount of TRAX immunoprecipitated by the anti-TRAX antibody was slightly higher than that from control cells (Fig. S6F). This finding is interesting because the anti-TRAX antibody was raised against the last 18 amino acids located in the C-terminus of TRAX [25]. It is possible that dissociation from its binding partners may expose the $\mathrm{C}$ terminus of TRAX, and result in a more efficient immunoprecipitation of TRAX. It is currently unknown whether $A_{2 A} R$ and TRAX are substrates of GSK3 $\beta$. Analyses using the NetPhos 3.1 Server [71] suggest that TRAX has one potential GSK3 phosphorylation site and that $\mathrm{A}_{2 \mathrm{~A}} \mathrm{R}$ has seven potential GSK3 phosphorylation sites located at its Cterminus where TRAX binds [25]. Further investigations are required to evaluate whether GSK3 $\beta$ regulates the formation of the $\mathrm{A}_{2 \mathrm{~A}} \mathrm{R} / \mathrm{TRAX}$ complex by direct phosphorylation of TRAX or $A_{2 A} R$ or through an indirect manner.

Stimulation of the $\mathrm{A}_{2 \mathrm{~A}} \mathrm{R}$ also effectively protects human MSN cells derived from iPSCs of HD patients from oxidative stress [34] and delays the symptoms of HD mice that suffer from high oxidative stress [30, 72, 73]. The binding of TRAX to the C-terminus of the $\mathrm{A}_{2 \mathrm{~A}} \mathrm{R}$ provides an efficient means by which to control the release of TRAX from the TRAX/DISC1/GSK3 $\beta$ complex and from $A_{2 A} R$, and may also facilitate other TRAX-dependent functions, including the transport of BDNF mRNA [55]. This is of great interest since the chronic blockade of the $\mathrm{A}_{2 \mathrm{~A}} \mathrm{R}$ in vivo markedly suppressed the neuronal plasticity mediated by BDNF in the hippocampus [74]. Because $A_{2 A} R$ agonists have been considered antipsychotic drugs [75], and the DISC1/TRAX locus is associated with schizophrenia [1417], the role of TRAX in mediating the actions following the activation of the $A_{2 A} R$ is of great importance and requires further investigation.
TRAX was identified 15 years ago and has been implicated in a wide variety of cellular functions ranging from nuclear machinery to events occurring in the cytoplasm. Studies from different laboratories suggest that TRAX exerts its functions via a direct interaction with different binding partners. Our study revealed at least two pathways (i.e., the stimulation of the $\mathrm{A}_{2 \mathrm{~A}} \mathrm{R}$ and the blockade of GSK3 $\beta$ ) to regulate the complex that TRAX binds to and shed new light on the role of GSK3/DISC1 in the NHEJ of oxidative DNA damage. Future investigation on the regulation of the TRAX/DISC1/GSK3 $\beta$ complex may pave the way for the development of novel therapeutic treatments for mental illness and neurodegenerative diseases with high oxidative DNA damage or/and poor DNA repair.

Acknowledgements This work was supported by grants from the Ministrant of Technology and Science of Taiwan (NSC96-2321-B001-015, NSC97-2321-B-001-012, and 100-2320-B-001-0110MY3 to Y Chern), and the Institute of Biomedical Sciences of Academia Sinica (103-Academia Sinica Investigation Award-06 to Y Chern).

\section{Compliance with ethical standards}

Conflict of interest The authors declare that they have no conflict of interest.

Open Access This article is licensed under a Creative Commons Attribution-NonCommercial-NoDerivatives 4.0 International License, which permits any non-commercial use, sharing, distribution and reproduction in any medium or format, as long as you give appropriate credit to the original author(s) and the source, and provide a link to the Creative Commons license. You do not have permission under this license to share adapted material derived from this article or parts of it. The images or other third party material in this article are included in the article's Creative Commons license, unless indicated otherwise in a credit line to the material. If material is not included in the article's Creative Commons license and your intended use is not permitted by statutory regulation or exceeds the permitted use, you will need to obtain permission directly from the copyright holder. To view a copy of this license, visit http://creativecommons.org/licenses/by-nc-nd/4.0/.

\section{References}

1. Odemis S, Tuzun E, Gulec H, Semiz UB, Dasdemir S, Kucuk M, et al. Association between polymorphisms of DNA repair genes and risk of schizophrenia. Genet Test Mol Biomarkers. 2016;20:11-17.

2. Raza MU, Tufan T, Wang Y, Hill C, Zhu MY. DNA damage in major psychiatric diseases. Neurotox Res. 2016;30:251-67.

3. Markkanen E, Meyer U, Dianov GL DNA damage and repair in schizophrenia and autism: implications for cancer comorbidity and beyond. Int J Mol Sci 2016;17:856.

4. Lieber MR. The mechanism of double-strand DNA break repair by the nonhomologous DNA end-joining pathway. Annu Rev Biochem. 2010;79:181-211.

5. Wang JF, Shao L, Sun X, Young LT. Increased oxidative stress in the anterior cingulate cortex of subjects with bipolar disorder and schizophrenia. Bipolar Disord. 2009;11:523-9.

6. Prabakaran S, Swatton JE, Ryan MM, Huffaker SJ, Huang JT, Griffin JL, et al. Mitochondrial dysfunction in schizophrenia: 
evidence for compromised brain metabolism and oxidative stress. Mol Psychiatry. 2004;9:684-97. 643

7. Steckert AV, Valvassori SS, Moretti M, Dal-Pizzol F, Quevedo J. Role of oxidative stress in the pathophysiology of bipolar disorder. Neurochem Res. 2010;35:1295-301.

8. Chan DW, Chen BP, Prithivirajsingh S, Kurimasa A, Story MD, Qin J, et al. Autophosphorylation of the DNA-dependent protein kinase catalytic subunit is required for rejoining of DNA doublestrand breaks. Genes Dev. 2002;16:2333-8.

9. Rass U, Ahel I, West SC. Defective DNA repair and neurodegenerative disease. Cell. 2007;130:991-1004.

10. Liu Y, Ye X, Jiang F, Liang C, Chen D, Peng J, et al. C3PO, an endoribonuclease that promotes RNAi by facilitating RISC activation. Science. 2009;325:750-3.

11. Aoki K, Ishida R, Kasai M. Isolation and characterization of a cDNA encoding a Translin-like protein, TRAX. FEBS Lett. 1997;401:109-12.

12. Laufman O, Ben Yosef R, Adir N, Manor H. Cloning and characterization of the Schizosaccharomyces pombe homologs of the human protein Translin and the Translin-associated protein TRAX. Nucleic Acids Res. 2005;33:4128-39.

13. Wu XQ, Gu W, Meng X, Hecht NB. The RNA-binding protein, TB-RBP, is the mouse homologue of translin, a recombination protein associated with chromosomal translocations. Proc Natl Acad Sci USA. 1997;94:5640-5.

14. Kilpinen H, Ylisaukko-Oja T, Hennah W, Palo OM, Varilo T, Vanhala R, et al. Association of DISC1 with autism and Asperger syndrome. Mol Psychiatry. 2008;13:187-96.

15. Thomson PA, Wray NR, Millar JK, Evans KL, Hellard SL, Condie A, et al. Association between the TRAX/DISC locus and both bipolar disorder and schizophrenia in the Scottish population. Mol Psychiatry. 2005;10:657-68. 616

16. Millar JK, Christie S, Semple CA, Porteous DJ. Chromosomal location and genomic structure of the human translin-associated factor X gene (TRAX; TSNAX) revealed by intergenic splicing to DISC1, a gene disrupted by a translocation segregating with schizophrenia. Genomics. 2000;67:69-77.

17. Schosser A, Gaysina D, Cohen-Woods S, Chow PC, Martucci L, Craddock N, et al. Association of DISC1 and TSNAX genes and affective disorders in the depression case-control (DeCC) and bipolar affective case-control (BACCS) studies. Mol Psychiatry. 2010;15:844-9.

18. Thomson PA, Malavasi EL, Grunewald E, Soares DC, Borkowska M, Millar JK. DISC1 genetics, biology and psychiatric illness. Front Biol. 2013;8:1-31.

19. Mao Y, Ge X, Frank CL, Madison JM, Koehler AN, Doud MK, et al. Disrupted in schizophrenia 1 regulates neuronal progenitor proliferation via modulation of GSK3beta/beta-catenin signaling. Cell. 2009;136:1017-31.

20. Ming GL, Song H. DISC1 partners with GSK3beta in neurogenesis. Cell. 2009;136:990-2.

21. Duff BJ, Macritchie KA, Moorhead TW, Lawrie SM, Blackwood DH. Human brain imaging studies of DISC1 in schizophrenia, bipolar disorder and depression: a systematic review. Schizophr Res. 2013;147:1-13.

22. Erdemir T, Bilican B, Oncel D, Goding CR, Yavuzer U. DNA damage-dependent interaction of the nuclear matrix protein C1D with Translin-associated factor X (TRAX). J Cell Sci. 2002;115 (Pt 1):207-16.

23. Wang JY, Chen SY, Sun CN, Chien T, Chern Y. A central role of TRAX in the ATM-mediated DNA repair. Oncogene. 2016;35:1657-70.

24. Sun CN, Chuang HC, Wang JY, Chen SY, Cheng YY, Lee CF, et al. The A2A adenosine receptor rescues neuritogenesis impaired by p53 blockage via KIF2A, a kinesin family member. Dev Neurobiol. 2010;70:604-21.
25. Sun CN, Cheng HC, Chou JL, Lee SY, Lin YW, Lai HL, et al. Rescue of p53 blockage by the $\mathrm{A}(2 \mathrm{~A})$ adenosine receptor via a novel interacting protein, translin-associated protein $\mathrm{X}$. Mol Pharmacol. 2006;70:454-66.

26. Boison D, Singer P, Shen HY, Feldon J, Yee BK. Adenosine hypothesis of schizophrenia-opportunities for pharmacotherapy. Neuropharmacology. 2012;62:1527-43.

27. Hirota T, Kishi T. Adenosine hypothesis in schizophrenia and bipolar disorder: a systematic review and meta-analysis of randomized controlled trial of adjuvant purinergic modulators. Schizophr Res. 2013;149:88-95.

28. Shen HY, Singer P, Lytle N, Wei CJ, Lan JQ, Williams-Karnesky $\mathrm{RL}$, et al. Adenosine augmentation ameliorates psychotic and cognitive endophenotypes of schizophrenia. J Clin Invest. 2012;122:2567-77.

29. Akhondzadeh S, Shasavand E, Jamilian H, Shabestari O, Kamalipour A. Dipyridamole in the treatment of schizophrenia: adenosine-dopamine receptor interactions. J Clin Pharm Ther. 2000;25:131-7.

30. Chou SY, Lee YC, Chen HM, Chiang MC, Lai HL, Chang HH, et al. CGS21680 attenuates symptoms of Huntington's disease in a transgenic mouse model. J Neurochem. 2005;93:310-20.

31. Villar-Menendez I, Diaz-Sanchez S, Blanch M, Albasanz JL, Pereira-Veiga T, Monje A, et al. Reduced striatal adenosine A2A receptor levels define a molecular subgroup in schizophrenia. J Psychiatr Res. 2014;51:49-59.

32. Hwang Y, Kim J, Shin JY, Kim JI, Seo JS, Webster MJ, et al. Gene expression profiling by mRNA sequencing reveals increased expression of immune/inflammation-related genes in the hippocampus of individuals with schizophrenia. Transl Psychiatry. 2013;3:e321.

33. Huang NK. Adenosine A2A receptors regulate oxidative stress formation in rat pheochromocytoma PC12 cells during serum deprivation. Neurosci Lett. 2003;350:127-31.

34. Chiu FL, Lin JT, Chuang CY, Chien T, Chen CM, Chen KH, et al. Elucidating the role of the A2A adenosine receptor in neurodegeneration using neurons derived from Huntington's disease iPSCs. Hum Mol Genet. 2015;24:6066-79.

35. Chang CP, Lee CT, Hou WH, Lin MS, Lai HL, Chien CL, et al. Type VI adenylyl cyclase negatively regulates GluN2B-mediated LTD and spatial reversal learning. Sci Rep. 2016;6:22529.

36. Liu H, Naismith JH. An efficient one-step site-directed deletion, insertion, single and multiple-site plasmid mutagenesis protocol. BMC Biotechnol. 2008;8:91.

37. Liu YJ, Ju TC, Chen HM, Jang YS, Lee LM, Lai HL, et al. Activation of AMP-activated protein kinase alpha1 mediates mislocalization of TDP-43 in amyotrophic lateral sclerosis. Hum Mol Genet. 2015;24:787-801.

38. Schneider CA, Rasband WS, Eliceiri KW. NIH Image to ImageJ: 25 years of image analysis. Nat Methods. 2012;9:671-5.

39. Olive PL, Banath JP. The comet assay: a method to measure DNA damage in individual cells. Nat Protoc. 2006;1:23-29.

40. Zhang G, Gurtu V, Kain SR, Yan G. Early detection of apoptosis using a fluorescent conjugate of annexin V. BioTechniques. 1997;23:525-31.

41. Koos B, Andersson L, Clausson CM, Grannas K, Klaesson A, Cane G, et al. Analysis of protein interactions in situ by proximity ligation assays. Curr Top Microbiol Immunol. 2014;377:111-26.

42. Yang ES, Wang H, Jiang G, Nowsheen S, Fu A, Hallahan DE, et al. Lithium-mediated protection of hippocampal cells involves enhancement of DNA-PK-dependent repair in mice. J Clin Invest. 2009;119:1124-35.

43. Sharma A, Singh K, Almasan A. Histone H2AX phosphorylation: a marker for DNA damage. Methods Mol Biol (Clifton, NJ). 2012;920:613-26.

44. Chang YH, Conti M, Lee YC, Lai HL, Ching YH, Chern Y. Activation of phosphodiesterase IV during desensitization of the 
A2A adenosine receptor-mediated cyclic AMP response in rat pheochromocytoma (PC12) cells. J Neurochem. 1997;69:1300-9.

45. Chen BP, Uematsu N, Kobayashi J, Lerenthal Y, Krempler A, Yajima $\mathrm{H}$, et al. Ataxia telangiectasia mutated (ATM) is essential for DNA-PKcs phosphorylations at the Thr-2609 cluster upon DNA double strand break. J Biol Chem. 2007;282:6582-7.

46. An J, Huang YC, Xu QZ, Zhou LJ, Shang ZF, Huang B, et al. DNA-PKcs plays a dominant role in the regulation of $\mathrm{H} 2 \mathrm{AX}$ phosphorylation in response to DNA damage and cell cycle progression. BMC Mol Biol. 2010;11:18.

47. Giambelluca MS, Cloutier N, Rollet-Labelle E, Boilard E, Pouliot $\mathrm{M}$. Expression and regulation of glycogen synthase kinase 3 in human neutrophils. Int J Biochem Cell Biol. 2013;45:2660-5.

48. Jeon SJ, Rhee SY, Ryu JH, Cheong JH, Kwon K, Yang SI, et al. Activation of adenosine A2A receptor up-regulates BDNF expression in rat primary cortical neurons. Neurochem Res. 2011;36:2259-69.

49. Goold RG, Gordon-Weeks PR. The MAP kinase pathway is upstream of the activation of GSK3beta that enables it to phosphorylate MAP1B and contributes to the stimulation of axon growth. Mol Cell Neurosci. 2005;28:524-34.

50. Sanchez JF, Sniderhan LF, Williamson AL, Fan S, ChakrabortySett S, Maggirwar SB. Glycogen synthase kinase 3beta-mediated apoptosis of primary cortical astrocytes involves inhibition of nuclear factor kappaB signaling. Mol Cell Biol. 2003;23:4649-62.

51. Dahoun T, Trossbach SV, Brandon NJ, Korth C, Howes OD. The impact of disrupted-in-schizophrenia 1 (DISC1) on the dopaminergic system: a systematic review. Transl Psychiatry. 2017;7: e1015.

52. Kang UG, Seo MS, Roh MS, Kim Y, Yoon SC, Kim YS. The effects of clozapine on the GSK-3-mediated signaling pathway. FEBS Lett. 2004;560:115-9.

53. Munkholm K, Poulsen HE, Kessing LV, Vinberg M. Elevated levels of urinary markers of oxidatively generated DNA and RNA damage in bipolar disorder. Bipolar Disord. 2015;17:257-68.

54. Yang S, Hecht NB. Translin associated protein X is essential for cellular proliferation. FEBS Lett. 2004;576:221-5.

55. Wu YC, Williamson R, Li Z, Vicario A, Xu J, Kasai M, et al. Dendritic trafficking of brain-derived neurotrophic factor mRNA: regulation by translin-dependent and -independent mechanisms. J Neurochem. 2011;116:1112-21.

56. Kuroda K, Yamada S, Tanaka M, lizuka M, Yano H, Mori D, et al. Behavioral alterations associated with targeted disruption of exons 2 and 3 of the Disc1 gene in the mouse. Hum Mol Genet. 2011;20:4666-83.

57. Chiu CT, Wang Z, Hunsberger JG, Chuang DM. Therapeutic potential of mood stabilizers lithium and valproic acid: beyond bipolar disorder. Pharmacol Rev. 2013;65:105-42.

58. Chuang DM, Wang Z, Chiu CT. GSK-3 as a target for lithium-induced neuroprotection against excitotoxicity in neuronal cultures and animal models of ischemic stroke. Front Mol Neurosci. 2011;4:15.

59. Freland L, Beaulieu JM. Inhibition of GSK3 by lithium, from single molecules to signaling networks. Front Mol Neurosci. 2012;5:14.
60. Luo J. Lithium-mediated protection against ethanol neurotoxicity. Front Neurosci. 2010;4:41.

61. Mohammadianinejad SE, Majdinasab N, Sajedi SA, Abdollahi F, Moqaddam MM, Sadr F. The effect of lithium in post-stroke motor recovery: a double-blind, placebo-controlled, randomized clinical trial. Clin Neuropharmacol. 2014;37:73-78.

62. Yang $\mathrm{Y}, \mathrm{Wu} \mathrm{N}$, Tian $\mathrm{S}, \mathrm{Li} \mathrm{F}, \mathrm{Hu} \mathrm{H}$, Chen $\mathrm{P}$, et al. Lithium promotes DNA stability and survival of ischemic retinal neurocytes by upregulating DNA ligase IV. Cell Death Dis. 2016;7: e2473.

63. Bucholtz N, Demuth I. DNA-repair in mild cognitive impairment and Alzheimer's disease. DNA Repair (Amst). 2013;12:811-6.

64. Ayala-Pena S. Role of oxidative DNA damage in mitochondrial dysfunction and Huntington's disease pathogenesis. Free Radic Biol Med. 2013;62:102-10.

65. Subba Rao K. Mechanisms of disease: DNA repair defects and neurological disease. Nat Clin Pract Neurol. 2007;3:162-72.

66. McKinnon PJ. DNA repair deficiency and neurological disease. Nat Rev Neurosci. 2009;10:100-12.

67. Beecham GW, Martin ER, Li YJ, Slifer MA, Gilbert JR, Haines $\mathrm{JL}$, et al. Genome-wide association study implicates a chromosome 12 risk locus for late-onset Alzheimer disease. Am J Hum Genet. 2009;84:35-43.

68. Tanaka M, Ishizuka K, Nekooki-Machida Y, Endo R, Takashima $\mathrm{N}$, Sasaki H, et al. Aggregation of scaffolding protein DISC1 dysregulates phosphodiesterase 4 in Huntington's disease. J Clin Invest. 2017;127:1438-50.

69. Carmichael J, Sugars KL, Bao YP, Rubinsztein DC. Glycogen synthase kinase-3beta inhibitors prevent cellular polyglutamine toxicity caused by the Huntington's disease mutation. J Biol Chem. 2002;277:33791-8.

70. Matsunaga S, Kishi T, Annas P, Basun H, Hampel H, Iwata N. Lithium as a treatment for Alzheimer's disease: a systematic review and meta-analysis. J Alzheimers Dis. 2015;48:403-10.

71. Blom N, Sicheritz-Ponten T, Gupta R, Gammeltoft S, Brunak S. Prediction of post-translational glycosylation and phosphorylation of proteins from the amino acid sequence. Proteomics. 2004;4:1633-49.

72. Ju TC, Chen HM, Lin JT, Chang CP, Chang WC, Kang JJ, et al. Nuclear translocation of AMPK-alpha1 potentiates striatal neurodegeneration in Huntington's disease. $\mathrm{J}$ Cell Biol. 2011;194:209-27.

73. Huang NK, Lin JH, Lin JT, Lin CI, Liu EM, Lin CJ, et al. A new drug design targeting the adenosinergic system for Huntington's disease. PloS One. 2011;6:e20934.

74. Jeronimo-Santos A, Batalha VL, Muller CE, Baqi Y, Sebastiao $\mathrm{AM}$, Lopes LV, et al. Impact of in vivo chronic blockade of adenosine A2A receptors on the BDNF-mediated facilitation of LTP. Neuropharmacology. 2014;83:99-106.

75. Borroto-Escuela DO, Pintsuk J, Schafer T, Friedland K, Ferraro L, Tanganelli S, et al. Multiple D2 heteroreceptor complexes: new targets for treatment of schizophrenia. Ther Adv Psychopharmacol. 2016;6:77-94. 